

\title{
Investment and rate of profit in a financial context: The French case
}

\author{
Mickaël Clévenot, Jacques Mazier
}

\section{To cite this version:}

Mickaël Clévenot, Jacques Mazier. Investment and rate of profit in a financial context: The French case. 2005. hal-00188616

\section{HAL Id: hal-00188616 https://hal.science/hal-00188616}

Preprint submitted on 19 Nov 2007

HAL is a multi-disciplinary open access archive for the deposit and dissemination of scientific research documents, whether they are published or not. The documents may come from teaching and research institutions in France or abroad, or from public or private research centers.
L'archive ouverte pluridisciplinaire HAL, est destinée au dépôt et à la diffusion de documents scientifiques de niveau recherche, publiés ou non, émanant des établissements d'enseignement et de recherche français ou étrangers, des laboratoires publics ou privés. 


\title{
Investment and rate of profit in a financial context: The French case
}

\author{
M. Clévenot and J. Mazier \\ CEPN-CNRS, University Paris-Nord UMR n ${ }^{\circ} 7115$ \\ clevenot@seg.univ-paris13.fr mazier@seg.univ-paris13.fr
}

December 2005

\begin{abstract}
:
The growth regime which prevailed in France since the middle of the 1980s is characterised by a recovery of profitability without durable resumption of growth or accumulation of productive capital. The financialization of this growth regime can be read in firms' balance sheet structure with rising shares of equities. Following a Post-Keynesian framework, the main determinants of capital accumulation and finance are analysed and tested at the level of non financial companies for France from flow of funds national accounts. The arbitration which seems to prevail between real and financial accumulation could contribute to explain the insufficient recovery of investment. Regarding firms' liability structure, two alternative approaches are considered, one in terms of indebtedness norm, the other in terms of arbitration between financing by debt and issuing shares.
\end{abstract}

\section{Résumé:}

Le régime de croissance qui s'est installé en France depuis le milieu des années 1980 se caractérise par une restauration du taux de profit sans reprise de la croissance, ni de l'accumulation du capital productif. La financiarisation de ce régime de croissance se lit dans la structure du bilan des entreprises marquée par le poids croissant des actions à l'actif comme au passif. Dans un cadre théorique Post-Keynésien, les principaux déterminants de l'accumulation du capital et des modes de financement sont analysés et testés au niveau des sociétés non financières pour la France à partir des comptes de patrimoine de l'INSEE. L'arbitrage qui parait s'établir entre accumulation réelle et financière pourrait contribuer à expliquer l'insuffisante reprise de l'investissement. S'agissant de la structure du passif des sociétés, deux approches alternatives sont envisagées, la première en termes de norme d'endettement, la seconde en termes d'arbitrage entre financement par endettement ou par émission d'actions .

Key words: finance, investment, portfolio behaviour, growth regime.

JEL classification: G11, E12, E22, C32. 


\section{Introduction}

The 1980s and 1990s have been marked in France by significant structural changes. After a profitability crisis during the 1970 s, the share of profits has recovered in the second half of the 1980s and capital's profitability has returned to levels close to those which prevailed at the end of the 1960s. However this movement has not led to a lasting recovery of growth and capital accumulation.

Recoveries of the end of the 1980s and 1990s have been of short duration and have been followed by marked slowdowns. Beyond a temporary retreat, mass unemployment persisted. This configuration, characterized by a restored profitability of capital but with limited gains of productivity and a persistent unemployment, led some authors to speak of a new mode of extensive accumulation (Vidal, 2002).

Changes that occurred at the financing level constitute another outstanding feature of the period. Increase of real interest rates since 1980, end of credit rationing, financial liberalization, development of direct finance, norm on equity return and boom of the stock exchange markets have deeply changed firms' financial structure and corporate governance. An abundant literature endeavoured to analyze the mode of financiarized accumulation and the patrimonial capitalism of the 1990s (Aglietta and Rebérioux, 2004; Duménil and Levy, 2004; Boyer, 2000; Chesnais, 1996; Plihon, 2002; Stockhammer, 2004).

The article seeks to characterize accumulation regimes during the 1980s and 1990s in France while being based on the flow of funds accounts of INSEE which provide coherent data in flows and stocks over the period 1978-2001. Thanks to a precise taking into account of financial assets and liabilities and capital gains, these data allow to implement a rigorous analysis of firms' financial behaviour. Determinants of productive investment, financial accumulation, debt behaviour and issue of shares will be successively studied.

The theoretical framework is Post-Keynesian, with the founder role played by Kalecki (1937; 1954). Minsky (1986) was one of the pioneers in the analysis of interactions between financial variables and investment which lead to periodic crises of over-accumulation and overindebtedness. Post-Keynesian modelling with the precursory work of Godley and Cripps (1983) and those more recent of Godley (1999), Godley and Lavoie (2001) and Taylor (2004) gives a rigorous macroeconomic framework to the formalization of real and financial interactions (Clévenot, 2003). The "stock-flow consistent approach", using the framework of flow of founds accounts, allows a synthetic analysis of companies' real and financial behaviours.

The paper is organized as follows. A second section draws main tendencies of the 1980s and 1990 s in France as regard profitability, real and financial accumulation and patrimonial structure of firms. A more detailed attention is paid to indicators of financial profitability. A third section specifies the theoretical framework on finance and investment. A fourth section recalls first econometric results regarding main behavioural functions, real and financial accumulation, indebtedness and liability structure. A last section concludes.

\section{The 1980s and 1990s in France: the settlement of a mode of financiarized accumulation}

\subsection{Profit and investment}

At the level of non financial companies two indicators of economic rate of profitability are used, the gross rate of profit and the rate of retained earnings. They are calculated using non financial assets, except housing, measured at the cost of renewal at the end of the year, which presents the disadvantage of accounting for only $50 \%$ of non-financial assets, but which is often used because being better articulated with the concept of productivity of capital. 
Figure 1: Economic rate of profit of non financial companies Gross rate of profit $=\mathrm{P} / \mathrm{p}_{\mathrm{k}} \mathrm{K}_{(-1)}$ and rate of retained earnings $=\mathrm{RE} / \mathrm{p}_{\mathrm{k}} \mathrm{K}_{(-1)}$ $\mathrm{P}=$ gross profit, $\mathrm{RE}=$ retained earnings, $\mathrm{p}_{\mathrm{k}} \mathrm{K}_{(-1)}=$ non financial assets

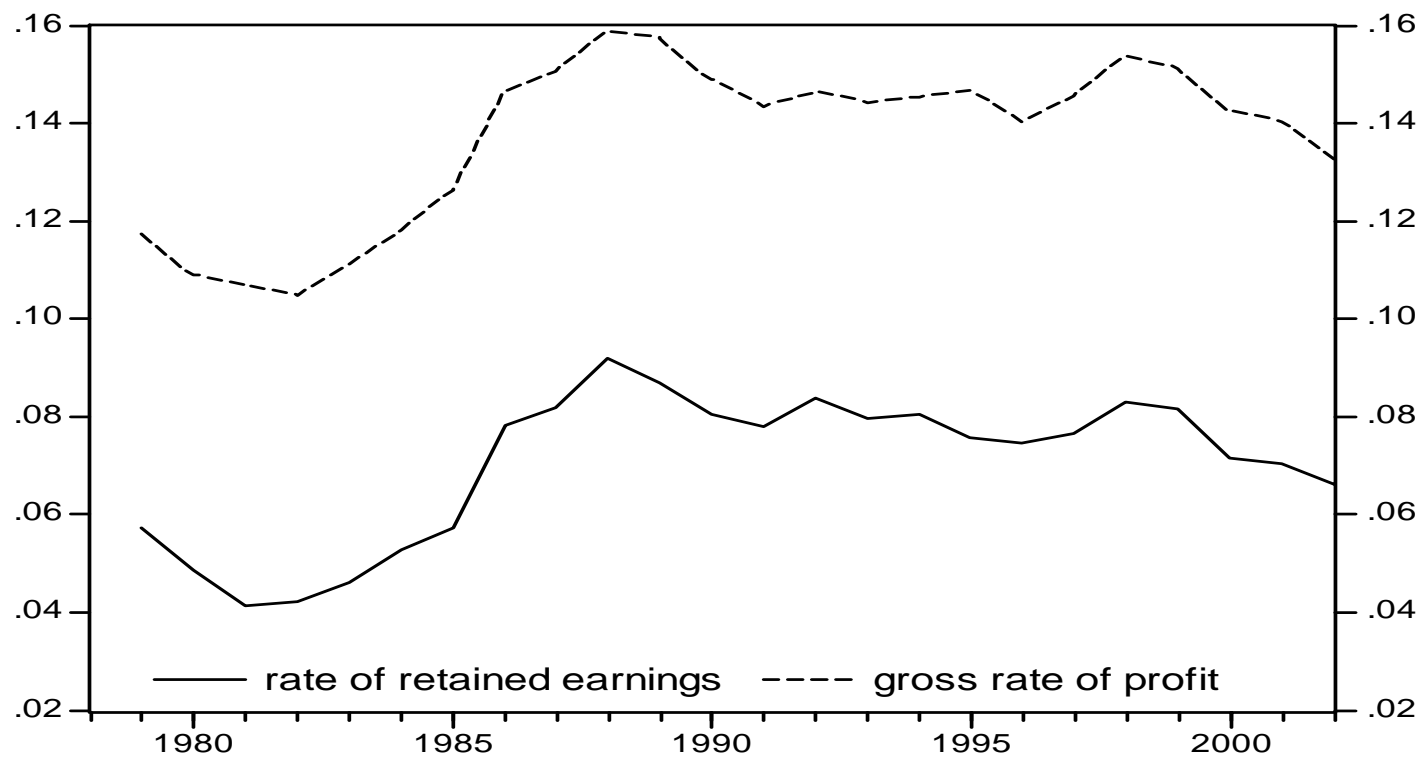

From the low point at the beginning of the 1980s the rate of profit has recovered in the second half of the decade to reach levels close to those of the end of the 1960s (Plihon, 2002; Duménil and Levy, 2004). It kept these high levels in spite of the economic slowdown of the beginning of the 1990s (figure 1).

This recovery of profitability is explained without surprise by the rising shares of profit and of retained earnings, like by the stabilization of the capital productivity (figures 2 and 3 ). The policy of competitive disinflation and the rise of unemployment were combined to slow down durably the progression of real wages and allow the restoration, then the maintenance at a high level of the share of profit, in spite of the limited growth of labour productivity.

Figure 2: Shares of profit in the value added of non financial companies Share of gross profit $=\mathrm{P} / \mathrm{p}_{\mathrm{y}} \mathrm{Y}$, share of retained earnings $=\mathrm{RE} / \mathrm{p}_{\mathrm{y}} \mathrm{Y}$

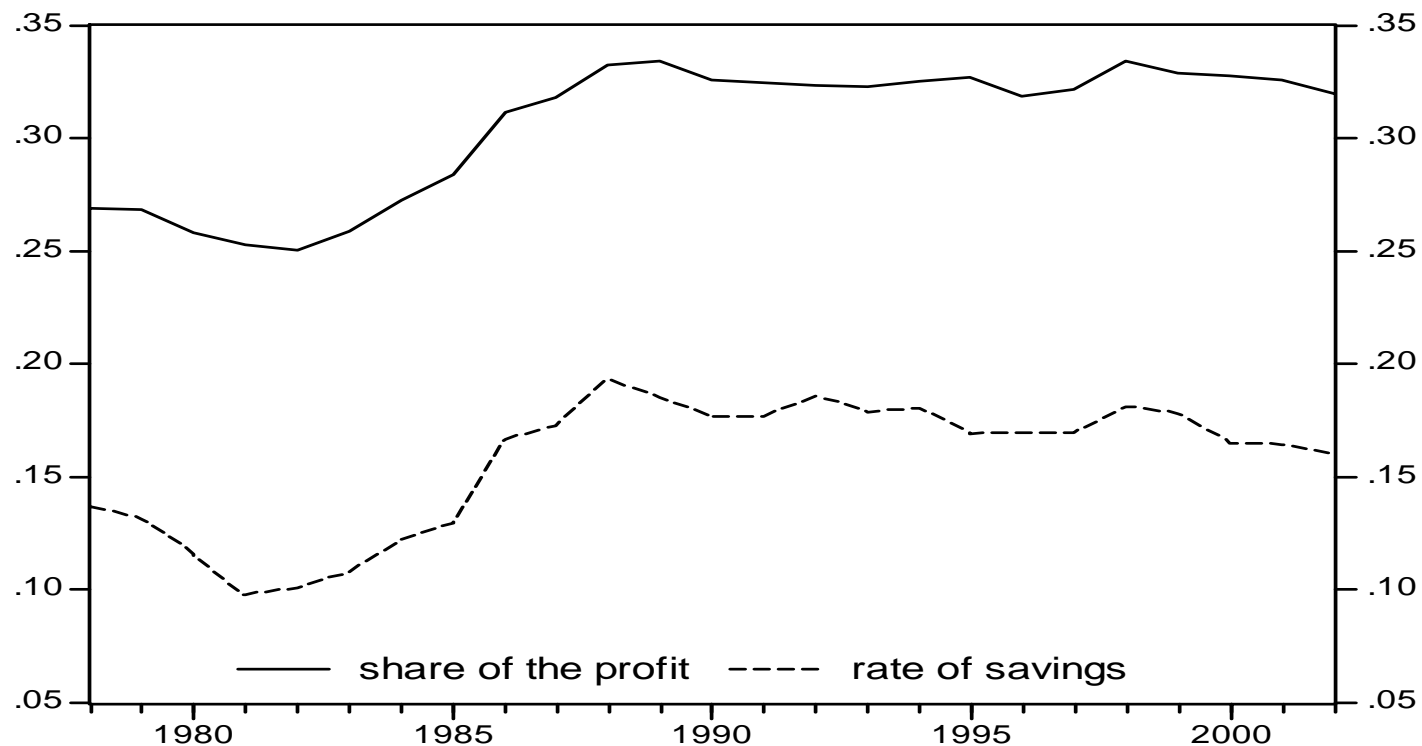


Figure 3: Capital productivity

$\mathrm{Y} / \mathrm{K}_{(-1)}=$ at the prices of 1995 and $\mathrm{p}_{\mathrm{y}} \mathrm{Y} / \mathrm{p}_{\mathrm{k}} \mathrm{K}_{(-1)}=$ at current prices

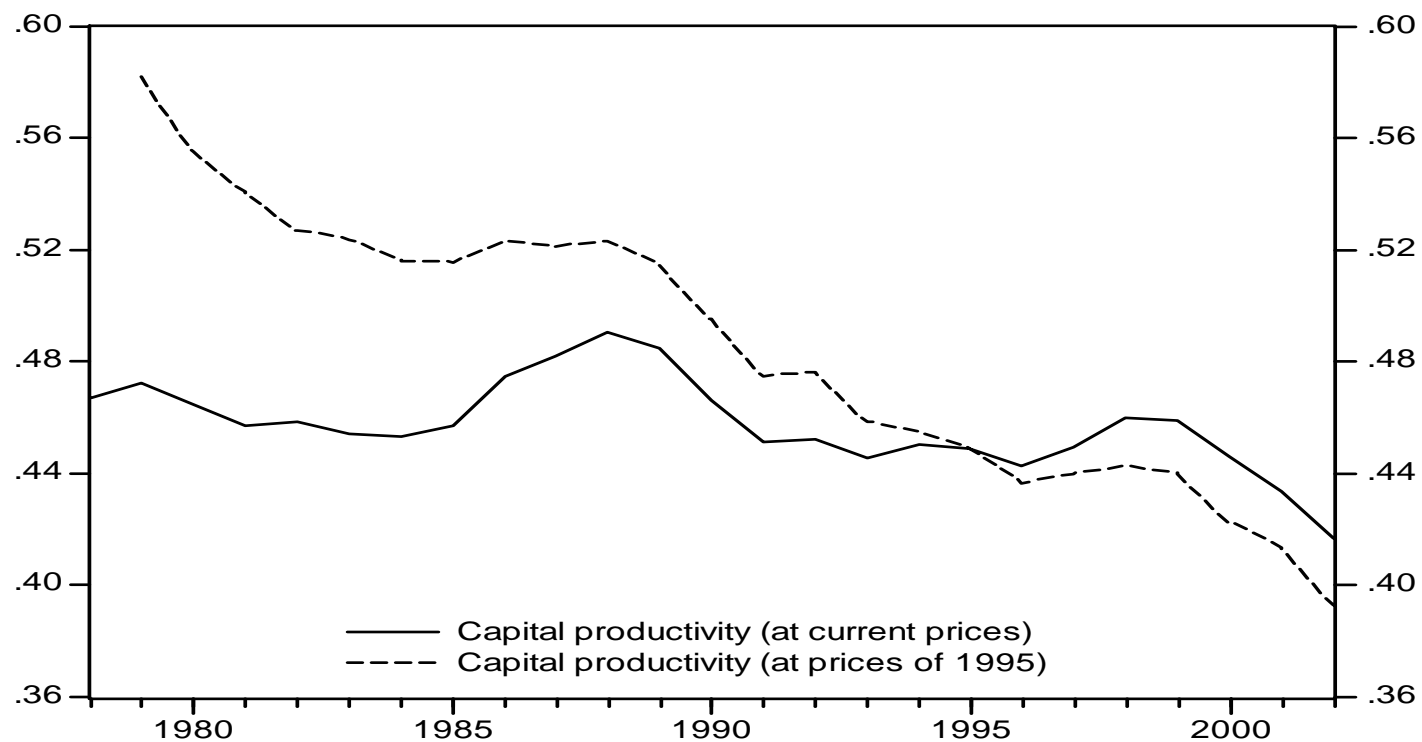

This restoration of profit however did not lead to a durable resumption of investment, nor, more generally, of the economic activity. Rate of investment and rate of accumulation ${ }^{1}$ knew significant falls at the beginning of each of both last decades. In 1990 and 2000 they only reached levels close to those of 1980, i.e. clearly in withdrawal of those of the beginning of the 1970s (figure 4). This fall of rate of investment is coherent with the decline of growth rate during the two cycles which followed each other after the opening of the crisis of profitability in 1974. But in the last cycle one can observe a disconnection between accumulation rate and rate of profit.

Figure 4: Trade-off between profit rate and accumulation rate during the 1990's

Gross rate of profit $=\mathrm{P} / \mathrm{p}_{\mathrm{k}} \mathrm{K}_{(-1)}$ and accumulation rate $=\mathrm{p}_{\mathrm{k}} \mathrm{I} / \mathrm{p}_{\mathrm{k}} \mathrm{K}_{(-1)}$

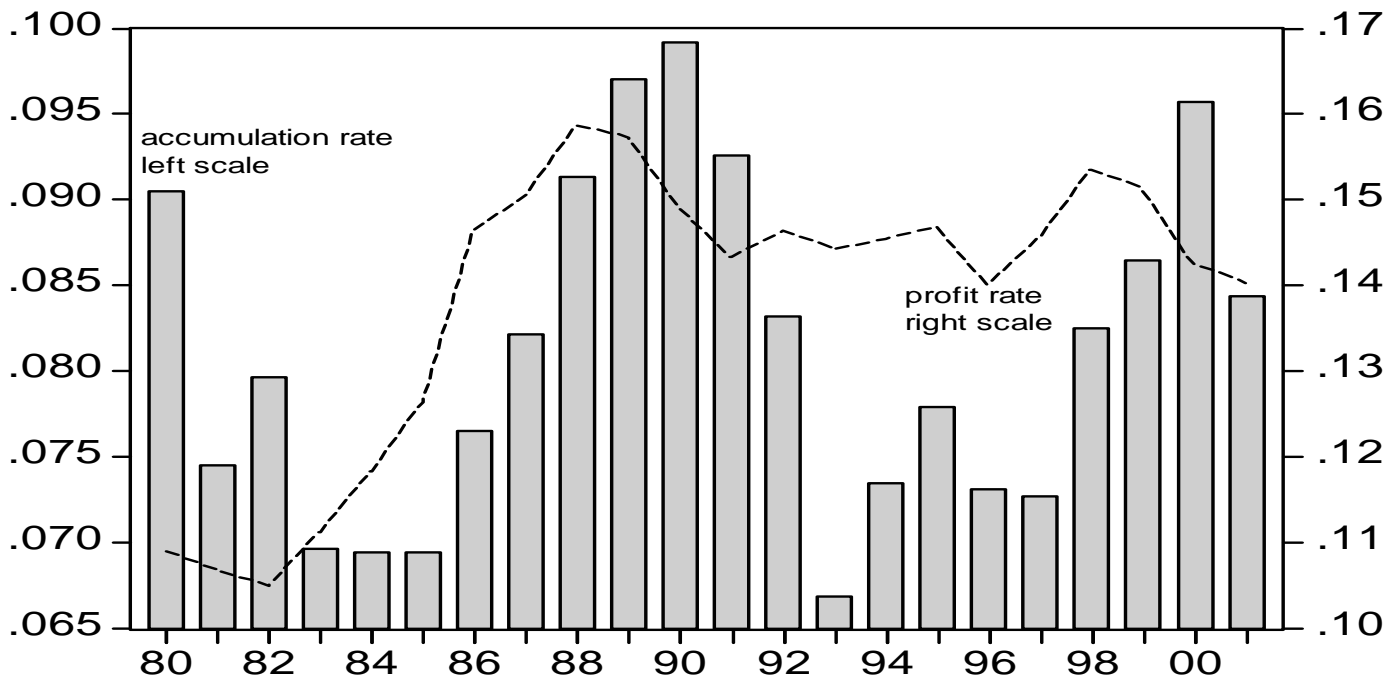

\footnotetext{
${ }^{1}$ The concept of investment used here is without housing, associated with non financial fixed assets without housing previously used.
} 
Since the end of the 1980s the recovery of rate of profit would have corresponded in France to an extensive growth regime characterized by a weak growth of labour productivity and the persistence of mass unemployment making pressure on real wages (Vidal, 2002; 2003). The comeback of finance power could be another explication to the weakness of growth in France and others OECD countries. At the opposite the United States draw advantage of their central position in financial activities with the depth of theirs financial markets and the position of dollar (Chesnais, 1996; Stochmammer, 2004). It would remain to study the stability and the sustainability of this growth regime.

\subsection{Financial liberalisation and financial structure of non financial companies}

The conjunction of a restored profit and a limited investment led to high rates of selffinancing since the end of the 1980s that only the erosion of retained earnings at the beginning of the 2000s has, partly, called into question. The financial liberalization leads to an increase of interest rates and an inversion of the leverage effect driving companies to centre on their heart of capabilities, i.e. on the most profitable activities, and to privilege their own founds.

\section{Firms' financing structure}

Firms' financing structure can be summarised in a very simplified way by aggregating the flow of net issued equities and the flow of net credit and by dividing the different financing sources by total investment, including housing (figure 5). It shows the prominent role plaid by retained earnings, as it has been already noted, the declining share of net credit, specially during the beginning of the 1980s and of the 1990s, and the limited contribution of net issued equities. This statement, although often made, must be interpreted cautiously as, apart from retained earnings, the two other sources of financing are consolidated and too aggregated.

Figure 5: Different sources of financing of non financial companies (in $\%$ of total investment, including housing)

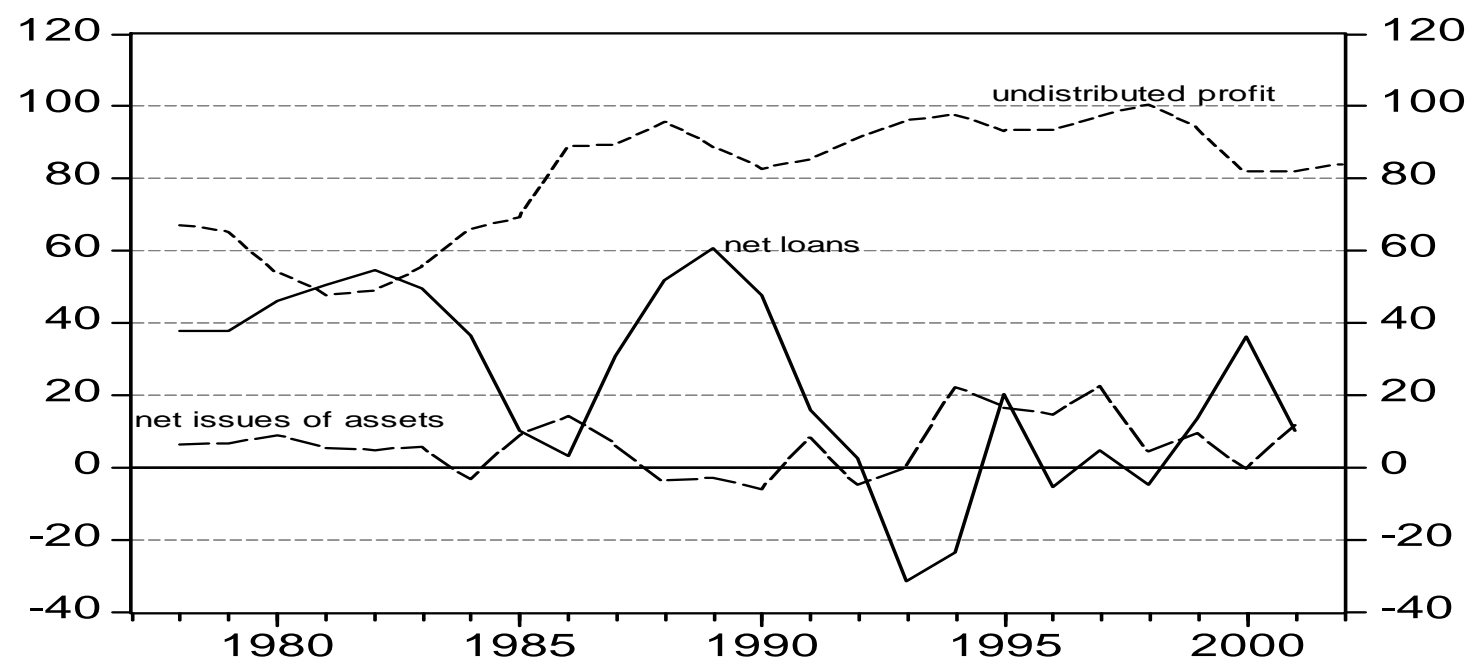

Main transformations induced by financial liberalization and burst of stock exchange markets can be better read at the level of firms' balance sheet. The accountable framework used is the INSEE flow of founds at the level of non financial companies. Insert 1 recalls main patrimonial variables. 


\begin{tabular}{|c|c|}
\hline \multicolumn{2}{|c|}{ Insert 1: Non financial companies' balance sheet } \\
\hline Asset & Liability \\
\hline \multicolumn{2}{|l|}{ Non financial asset $\left(\mathrm{p}_{\mathrm{k}} \mathrm{K}\right)$} \\
\hline $\begin{array}{l}\text { Financial assets (FA) } \\
\text { Monetary assets }(\mathrm{M}) \\
\text { Other assets (OA) } \\
\text { Equities (peEe) }\end{array}$ & $\begin{array}{l}\text { Financial liabilities (FL) } \\
\text { Loans (L) } \\
\text { Other liabilities (OL) } \\
\text { Equities (peE) }\end{array}$ \\
\hline Total asset $(\mathrm{A})$ & Net Wealth (NW) \\
\hline \multicolumn{2}{|c|}{$\begin{array}{l}\text { Financial Assets }=F A=\text { Monetary assets }(M)+\text { Other assets }(\mathrm{OA})+\text { Equities held }(\mathrm{pe} \mathrm{Ee}) \\
\text { Total Assets }=\mathrm{A}=\text { Non financial assets }\left(\mathrm{p}_{\mathrm{k}} \mathrm{K}\right)+\text { Financial assets }(\mathrm{FA})\end{array}$} \\
\hline \multicolumn{2}{|c|}{$\begin{array}{l}\text { Financial liabilities }=\mathrm{FL}=\text { Loans }(\mathrm{L})+\text { Other liabilities }(\mathrm{OL})+\text { Equities issued }(\text { pe E) } \\
\text { Own Funds }=\mathrm{OF}=\text { Net Wealth }(\mathrm{NW})+\text { Equities issued }(\text { pe E) } \\
\text { Total asset }(\mathrm{A})=\text { Total loans }(\mathrm{L}+\mathrm{OL})+\text { Own funds }(\mathrm{OF})\end{array}$} \\
\hline
\end{tabular}

\section{Firms' liability structure}

On the liability side (figure 6), non financial companies' debt was reduced in a significant way in two successive waves, first at the end of the 1980s in a context of restoration of profit, then at the end of the 1990s with the boom of the stock exchange, this whatever the indicator used: debt in a strict sense or in the broad sense, expressed as a percentage of total assets, debt expressed as a percentage of own founds. Equities boom plays the main role in these evolutions.

Financialization can also be read through the rise of Tobin's Q, either measured by using the $\mathrm{Q} 1$ ratio dividing equities by non-financial assets, or by using the $\mathrm{Q} 2$ ratio dividing equities by own founds. Equities prices fall since 2001 has obviously brought a corrective measure (figure 7).

Figure 6: Debt structure of non financial companies

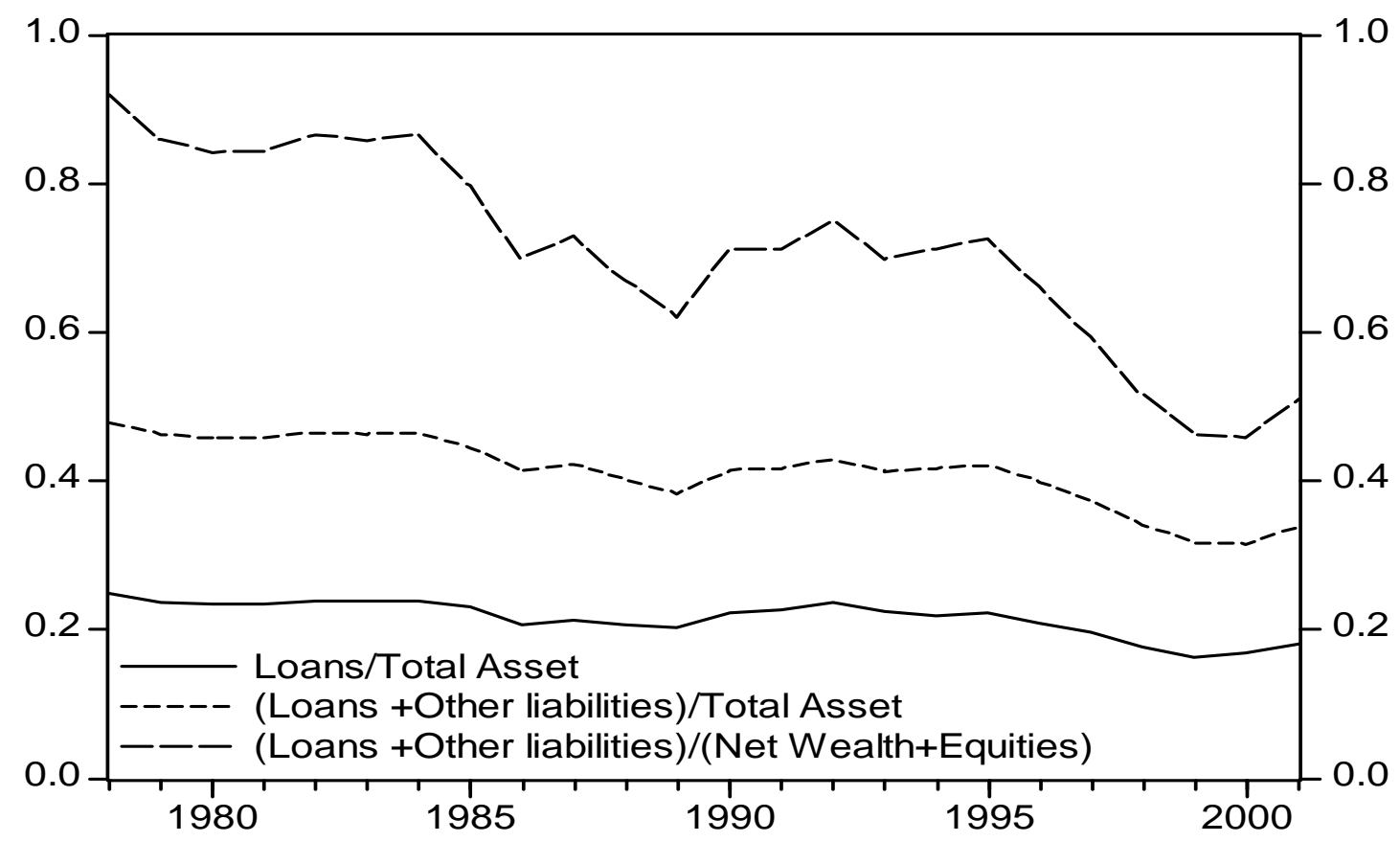


Figure 7: Tobin's Q

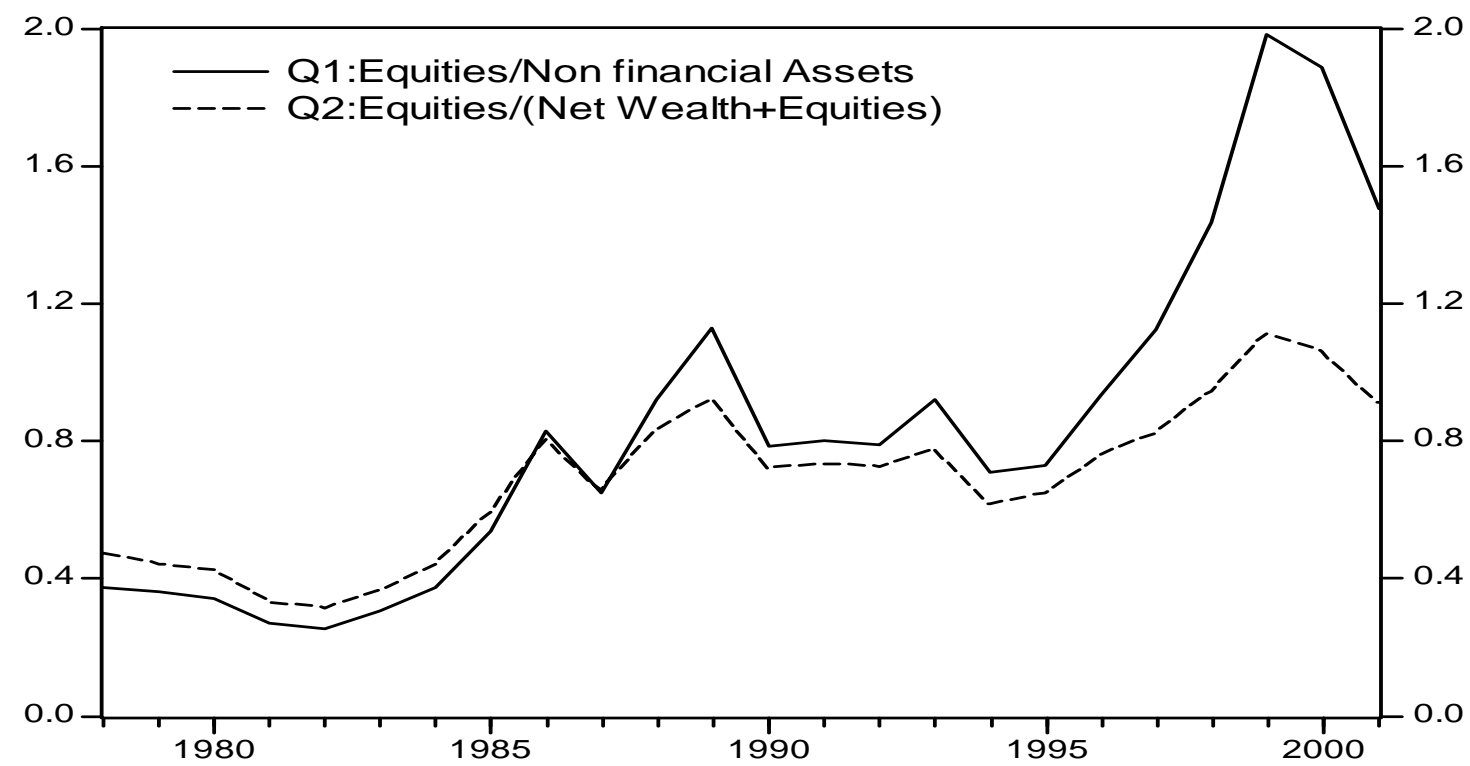

However a stock-flow ratio, in terms of capacity of refunding, dividing total debt at the beginning of the period by gross profit leads to a different assessment as regards debt. The ratio is more stable in long period. It has decreased quickly in the middle of the 1980s during the profit restoration, but has increased with the recovery of the end of the 1980s to reach levels close to those of the end of the 1970s (figure 8). This observation can lead to put into perspective the idea of a pronounced debt reduction of non financial companies since the 1980 s.

Figure 8: Capacity of refunding of non financial companies

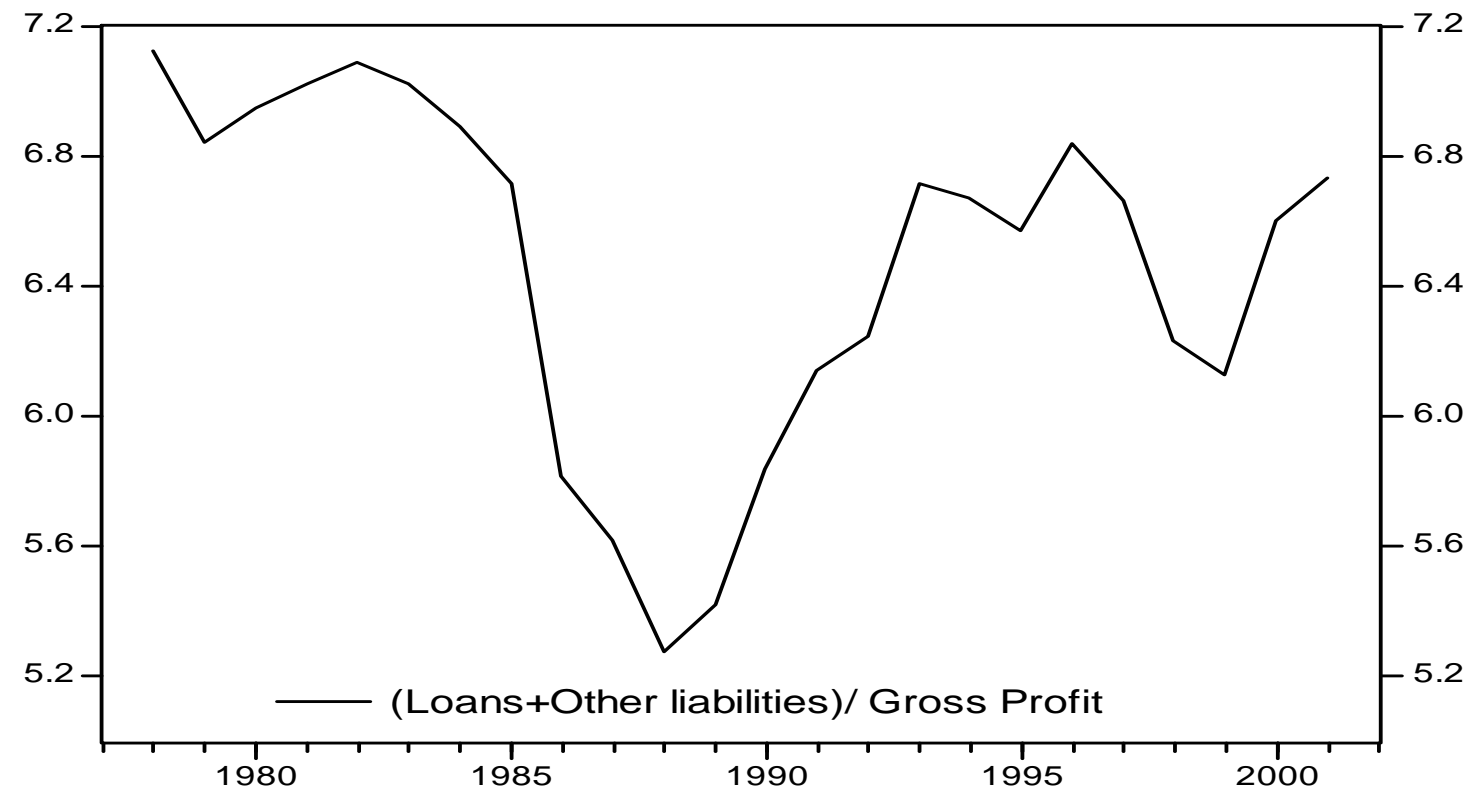




\section{Firms' asset structure}

On the asset side changes appear more spectacular with the rise of the share of equities in financial assets or in total assets. This evolution reflects at the same time the development of taking of financial stake in another company, including in foreign companies, and the very favourable trend of equities prices which inflates the value of these assets. Conversely, the share of the monetary assets and of others assets has decreased (figure 9).

Figure 9: Structure of assets of non financial companies

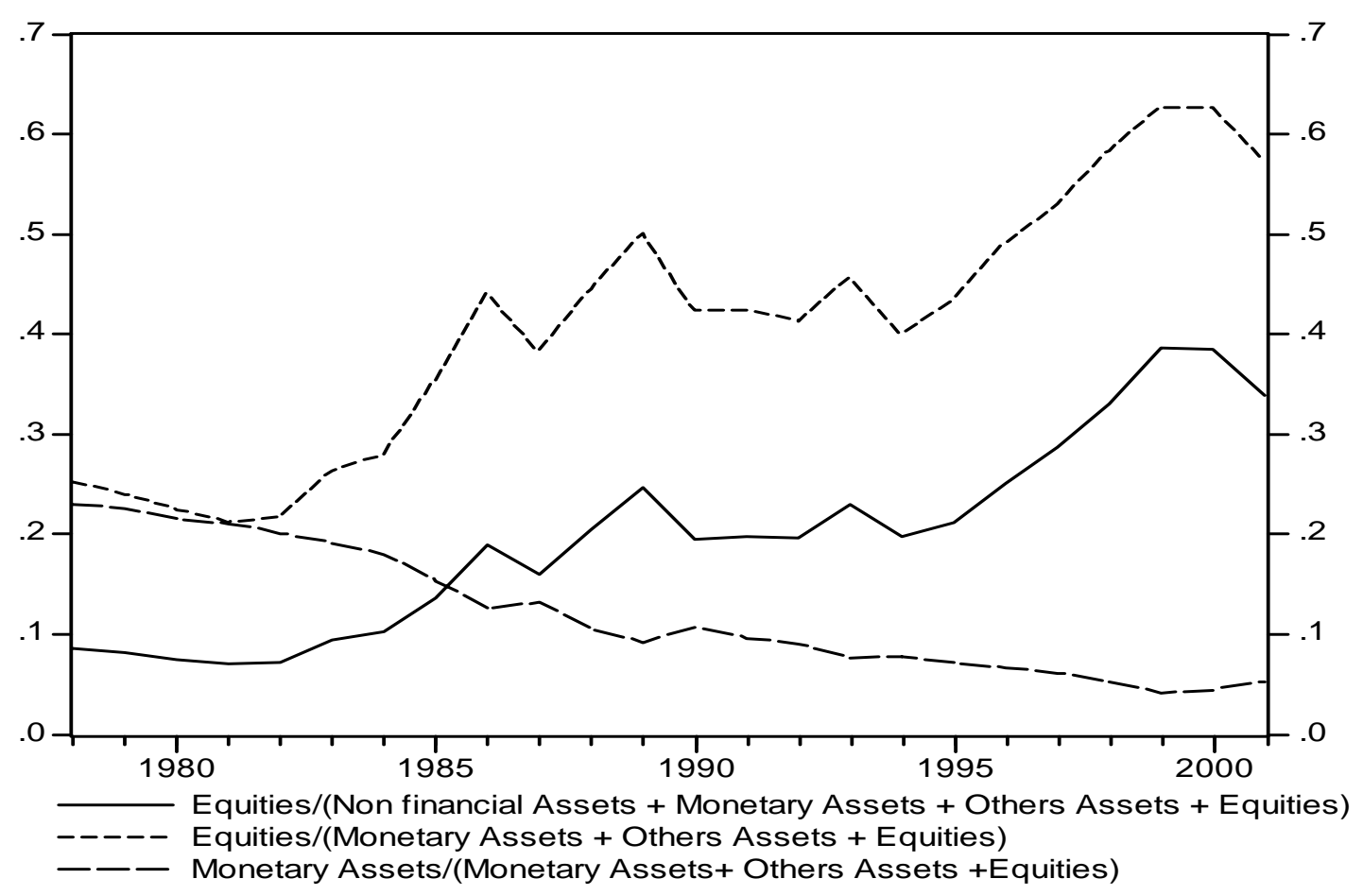

Transformations which have affected asset and liability structures of non financial companies since the 1980s are the reflection of major changes induced by the financial liberalization with deregulation, decompartmentalization of the markets and the rise of direct finance. Financial assets have increased while stock exchange markets knew a boom starting from the second half of the 1990s. The parallel evolutions of asset and liability structures, such as they are described in the INSEE flows of funds accounts, reflect mainly this price effect which has simultaneously revalorized equities held by non financial companies and their own founds (figure 10). The share of equities held in financial assets and the share of equities in the financial liability seem largely determined by equities prices measured by the SBF 250 index representative of equities prices.

These data, especially equities held by non financial companies, should be interpreted cautiously because they are not consolidated at macroeconomic level and includes the taking of financial stake in other domestic companies. In some studies (Bataille et Durand, 2005) equities on asset and liability sides are simply consolidated to eliminate the inter-firms participations, which considerably reduce the share of equities on the liability side. This kind of approach can be criticised for at least two reasons. Firstly, equities of foreign firms which figure as financial assets are ignored, although they now represent a significant share of the total. Secondly, financial behaviour of companies has deeply changed during the 1990s and the taking of financial stake reflects a strong trend which must not be underestimated or ignored. This explains we have preferred to keep the gross data without consolidation. 
Figure 10: Asset and liability structure of non financial companies and equities prices

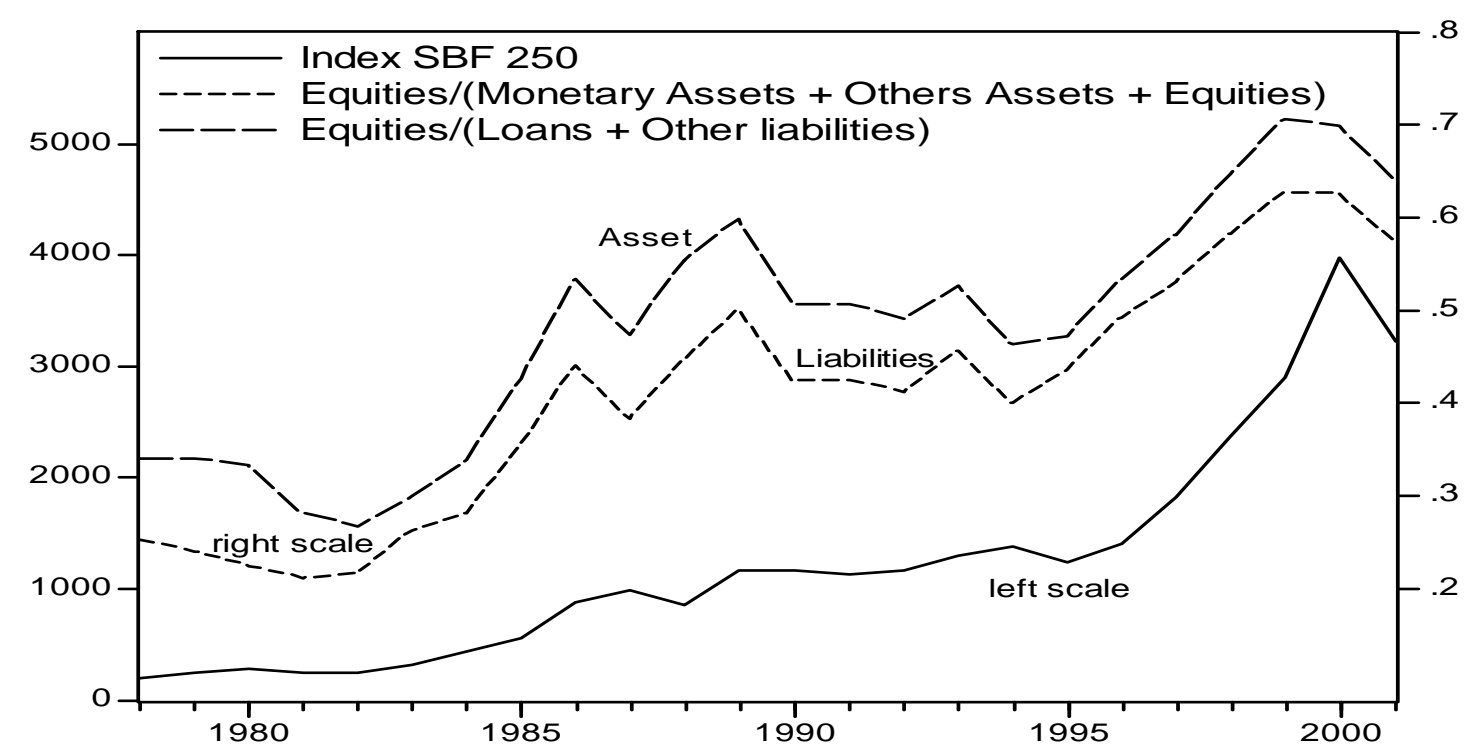

\section{Financial burden}

The financial burden induced by payments of interests and distributed dividends are a last characteristic of the growth regime since the 1980s which has to be examined. Interest rates have known a major rupture in 1979 following the change operated as regards monetary policy and the will to ensure a better remuneration for financial assets.

In spite of the progressive fall of nominal rates with the inflation slow down, real interest rates have remained very high in France until the first half of the 1990s, partly because of tensions existing within the EMS. The decline of real interest rates appeared only in the second half of the 1990s. Beside short-term and long-term interest rates, the apparent interest rate, which relates interests paid to the stock of debt, gives another measure of the cost of debt for non financial companies. Its profile is slightly different. The initial rise is more progressive, but the apparent rate remains more durably high, especially in real terms (figures 11 and 12).

Figure 11: Nominal interest rates (apparent interest rate = interest paid/ total loans)

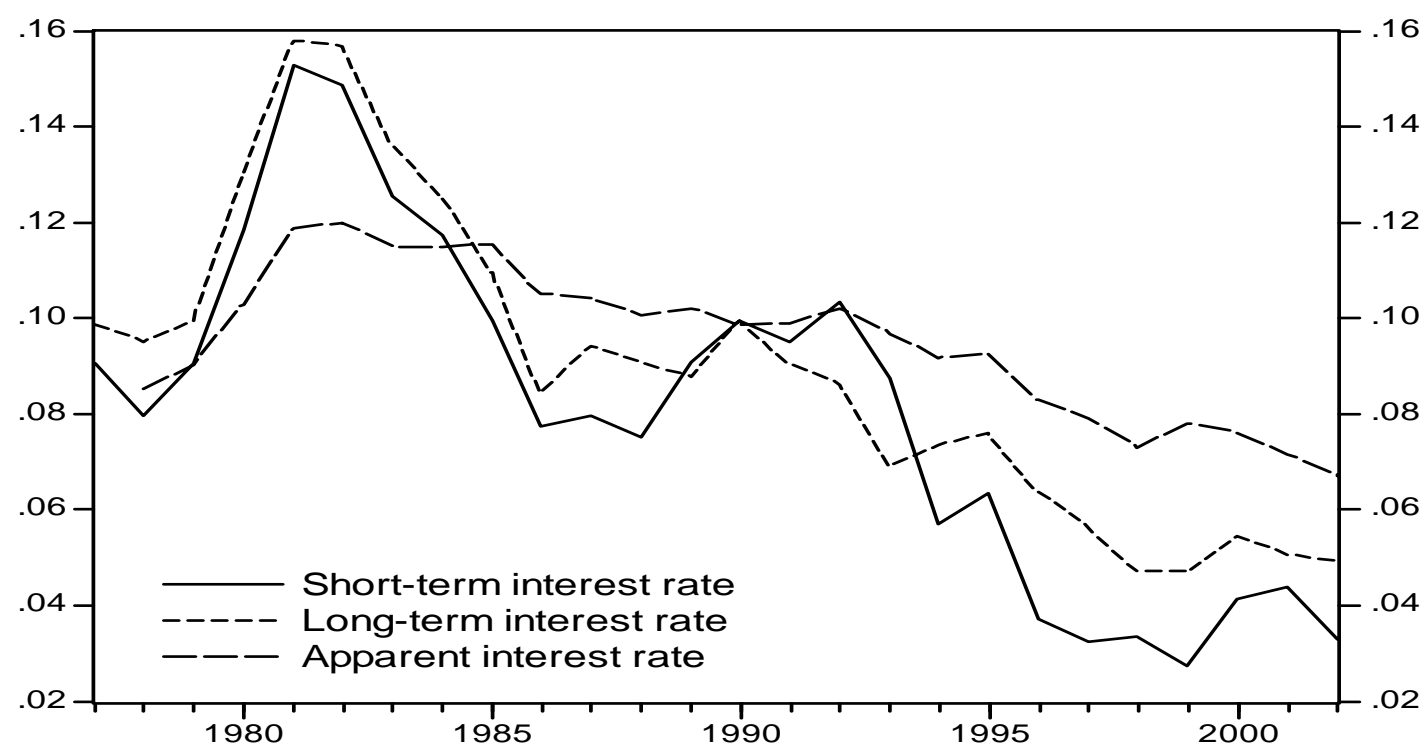


Figure 12: Real interest rates (deflated by GDP price)

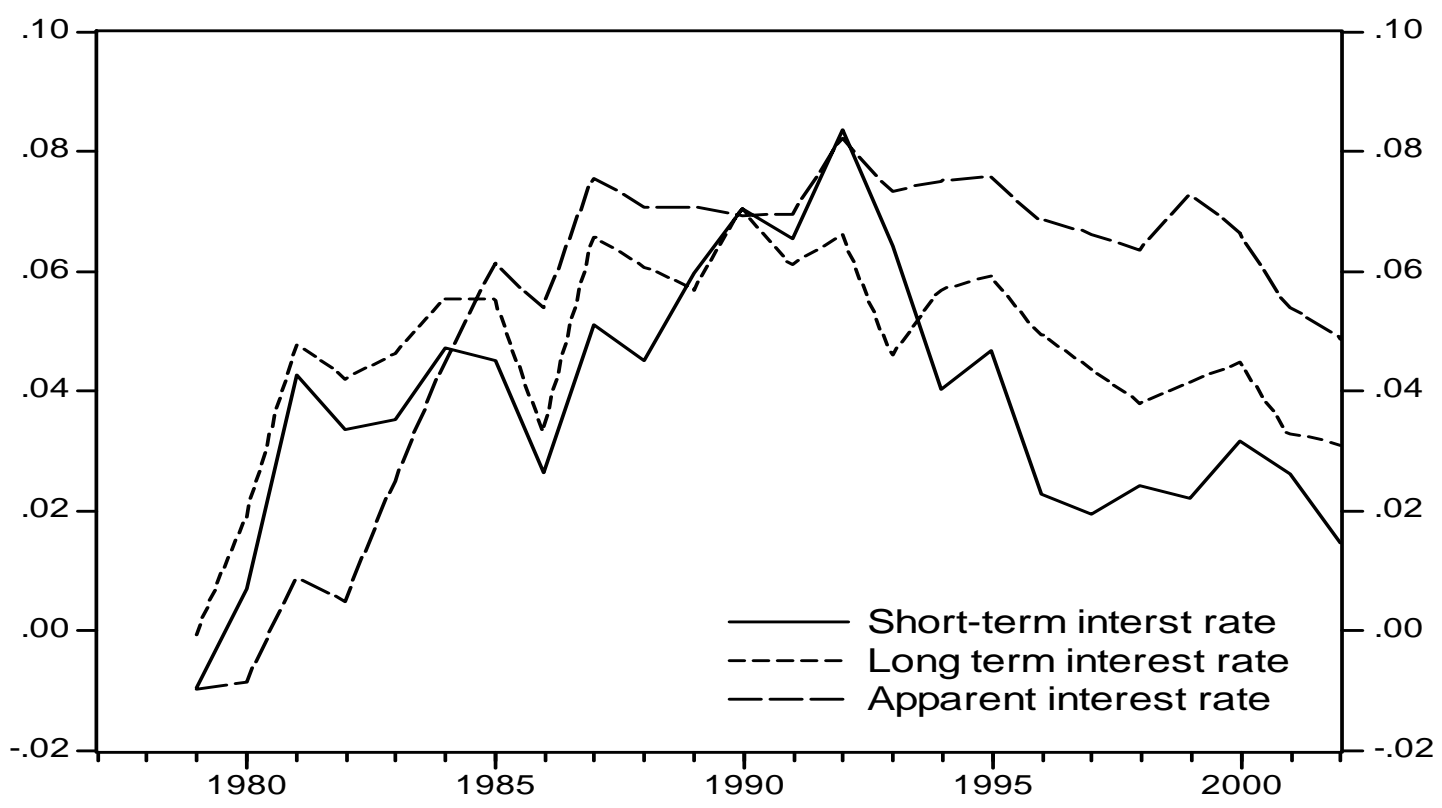

The financial burden itself can be apprehended through two ratios, the share of interests paid in gross profit, which decreased in the second half of the 1990s because of the fall of nominal and real interest rates, and the share of dividends paid in gross profit, which quickly increased on the contrary during the 1990 s, so as to ensure a better remuneration of shareholders. The total financial burden, sum of the two preceding ratios, increased appreciably (figure 13).

Figure 13: Financial burden in \% of gross profit



To have a more accurate vision of the puncture operated by the finance on profit, interests and dividends received by firms have to be considered to get a net burden. Results are quite different (figure 14). After an increase at the beginning of the 1980s due to the rise of interest rates, the net financial burden in percentage of gross profit declined and remained stable around 35\%. This is explained by the sustained growth of financial income during the 1990s in connection with the rise of financial assets. If on the whole, the puncture operated by 
finance on profit remained stable, the financialization has probably produced redistributive effects between firms. Those who were not able to develop their financial assets, specially the small ones, have been more directly touched (Arestis, 2004).

Figure 14: Net financial burden in \% of gross profit



\subsection{Paradoxes of the financial profitability}

Beside economic profitability, various indicators seek to determine financial profitability calculated with respect to own founds. To facilitate the comparisons, one retains first a gross financial rate of profit, before financial deduction. This rate surprises, not so much by its level compared with that of economic profitability (comparisons in level have a limited significance) as by its evolution. Financial profitability decreased continuously since the end of the 1980s, which contradicts available information on companies (figure 15).

Figure 15: Economic rate of profit and financial rate of profit (profit/own funds)

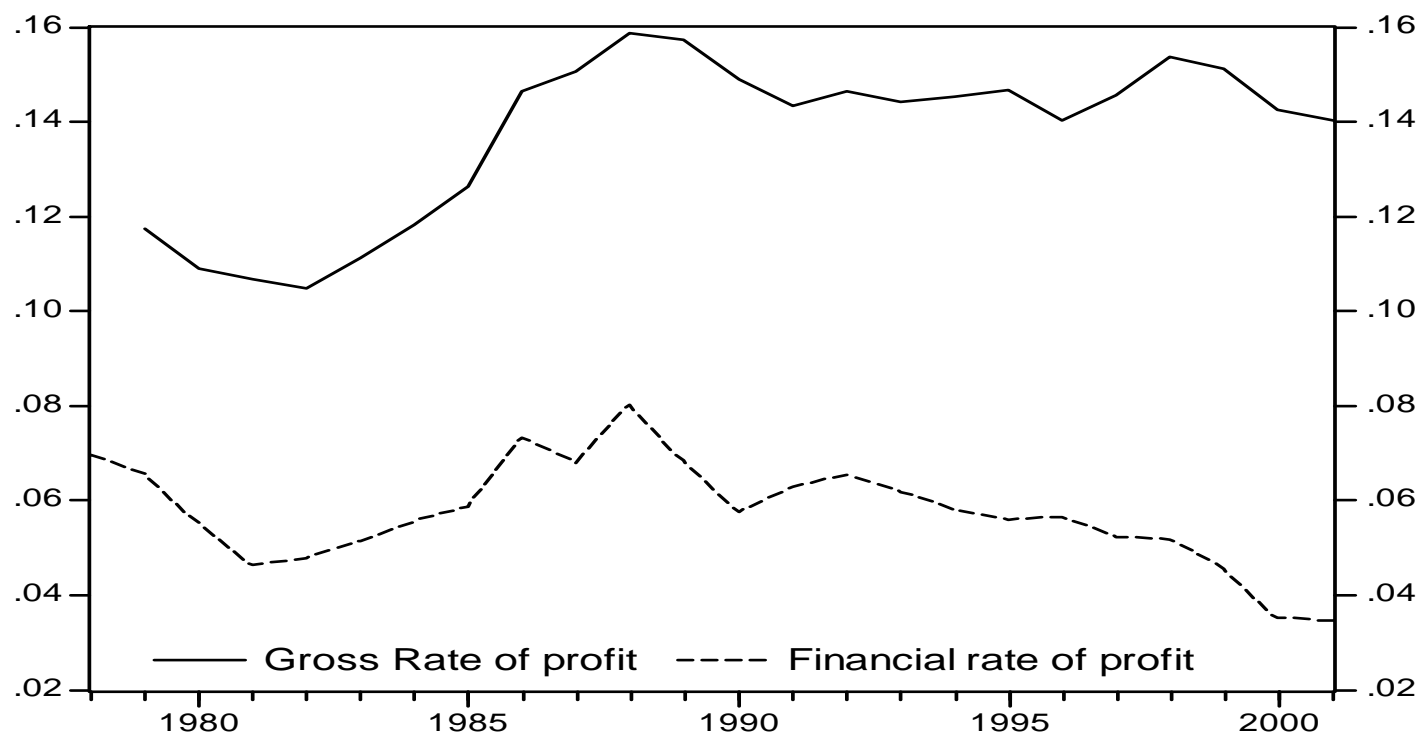


This result is explained in several ways (Plihon, 2002). Flow of founds accounts are built like an aggregation of not consolidated accounts, estimated at market values, which tends with cross participations to simultaneously inflate asset and liability of non financial companies, without increasing profit at the numerator in the same proportion. With the rise of share prices and the re-evaluation which results, net wealth and owns founds of non financial companies are revalorized without taking into account capital gains in the measurement of profit. Consequently, a considerable skew appeared in the measurement of financial profitability such as it is proposed, whereas the ROE (return on equity), traditionally used on data of companies, incorporates the exceptional incomes with the realized capital gains.

Another macroeconomic indicator of financial profitability suggested by Godley and Lavoie (2001) appears preferable. The rate of return on equities (re) is the sum of distributed dividends and capital gains divided by the value of equities issued by non financial companies and registered at their liability. In the same way, the rate of return of equities held by non financial companies (ree) is the sum of received dividends and capital gains divided by the value of equities held at the asset of non financial companies (figure 16).

The rate of return on equities is very fluctuating. Fluctuations are mainly determined by capital gains, i.e. by the growth rate of equities price, the ratio dividends on equities being very stable. The rate of variation of share prices representative index (CAC 40; IP 250) appears obviously much correlated with the rate of return on equities. Peaks of financial profitability, with nearly $60 \%$ and $40 \%$ respectively in 1986 and 1999, alternate with negative profitability during stock exchange crises, as in 1987 and 2001. Although fluctuations are much larger, a comparison can be made with variations of the ROE calculated for non financial companies of the CAC 40 (Plihon, 2002). The average of equities yield is 16 $\%$ during the period 1978- 2001.

Figure 16: Rate of return on equities issued and held by non financial companies and rate of variation of equity prices

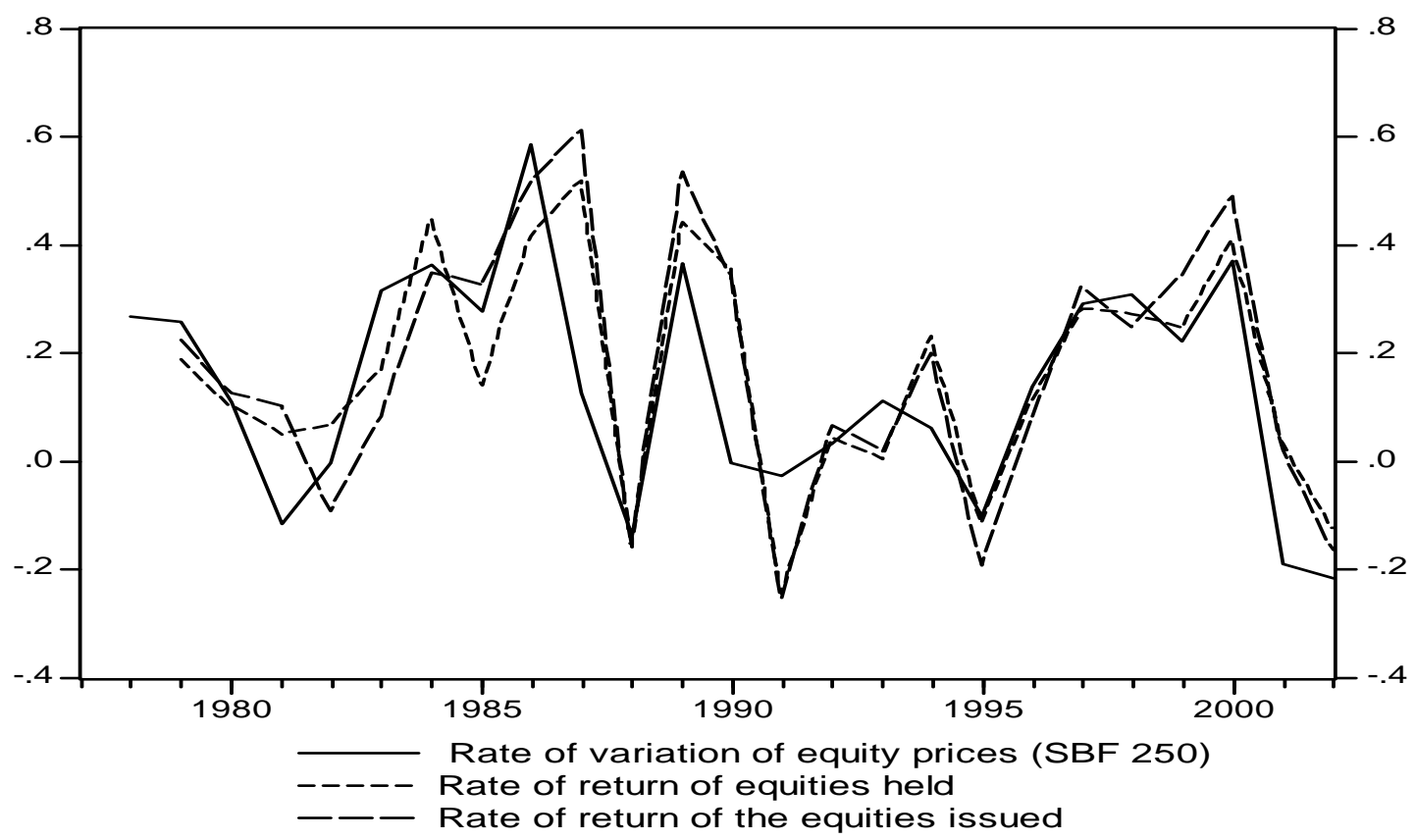


re $=$ rate of return on equities $=($ capital gains $+\mathrm{DD}) /\left(\right.$ pe E) ${ }_{(-1)}, \mathrm{CG}=$ capital gains on equities $=\mathrm{E}_{(-1)} \Delta \mathrm{pe}, \mathrm{DD}=$ distributed dividends

$\mathrm{re}=(\mathrm{CG}+\mathrm{DD}) / \mathrm{peE}(-1)=\left(\mathrm{E}_{(-1)} \Delta \mathrm{pe}+\mathrm{DD}\right) /(\mathrm{peE})_{(-1)}=\Delta \mathrm{pe} / \mathrm{pe}_{(-1)}+\mathrm{DD} /(\mathrm{peE})_{(-1)}$

ree $=$ rate of return on equities held $=($ capital gains $+\mathrm{RD}) /(\text { pe Ee })_{(-1)}, \mathrm{CGe}=$ capital gains on equities held $=\mathrm{Ee}_{(-1)} \Delta$ pe, $\mathrm{RD}$ : received dividends.

$\mathrm{ree}=(\mathrm{CGe}+\mathrm{RD}) / \mathrm{peEe}_{(-1)}=(\mathrm{Ee}-1 \Delta \mathrm{pe}+\mathrm{RD}) /(\mathrm{peEe})_{(-1)}=\Delta \mathrm{pe} / \mathrm{pe}_{(-1)}+\mathrm{RD} /(\mathrm{peEe})_{(-1)}$

$\mathrm{pe}=$ equities price, $\mathrm{E}=$ number of equities issued, $\mathrm{Ee}=$ number of equities held

On the whole, the growth regime which settled in France since the second half of the 1980s is characterized by a recovery of profit share and of the economic profitability, but without durable resumption of capital productive accumulation. The financialization of this growth regime appears in a less call for debt and in the increasing share occupied by equities, both on the liability and asset sides of non financial companies.

Starting from high levels, the fall of inflation rate and of nominal interest rates appeared since the middle of the 1980s, while the fall of real rates occurred only in the second half of the 1990s. In this context stock exchange prices flew away in two successive waves, stopped by crashes of 1987 and 2001. These flights contributed to the revalorization of own founds and of equities held by non financial companies, while financial profitability knew cyclic evolutions of large amplitude.

\section{A Post-Keynesian analysis framework}

\subsection{Finance and investment: a controversial matter}

The existence of a relation between flow of funds structure and investment is opposed to the Modigliani-Miller theorem (1963) which shows the neutrality of financing sources on companies' investment. Movements recorded in the financial structure of companies and the increasing share of equities during the last twenty years suggest on the contrary that there is powerful financial action leverage. The strategic dimension of finance has been evacuated with the assumption of perfect information. It is this central assumption which is more and more released by the neo-Keynesian theory. It leads to a widening effect of monetary policy on economic activity, via the investment and the broad channel of credit. The first manner of taking account explicitly of these effects was implemented by Tobin and Brainard (1969). Tobin Q rests on the idea that a company can grow in two manners, either by organic growth or by external growth.

The choice consists in carrying out arbitration between productive investment and purchase of financial assets. The microeconomic intuition which prevails is extended at macroeconomic level by supposing a perfect financial market in the medium term. At this level, the Tobin Q is defined as the financial value of the company, measured with issued equities evaluated at market prices, divided by the "physical" capital of the company evaluated at the renewal costs. Theoretically the equilibrium value of the Tobin $\mathrm{Q}$ must be equal to the unit, meaning the equivalence between the financial value of the company and its fundamental value. Actually, two situations can be observed. When financial value is lower than the "real" value of the company (the ratio is lower than the unit), contractors are incited to reduce the size of their company and buy assets of others companies. When financial value is higher than fundamental value, one must observe an increase of real investment which is less expensive than external growth. Thus the theory describes a positive relation between physical investment and Tobin Q.

But empirical analyses pain to establish a clear relation between Tobin's Q and the accumulation's rate. In the French case Epaulard (1993) distinguished two periods in her 
sample, justified by transformations carried out on French financial markets, to establish a stable relation between the rate of accumulation and Tobin's Q. For countries of the G7 Davis (2001) shows that Tobin's Q is far from playing systematically. More recently, some authors have identified a positive relation between Tobin's Q and purchase of equities by companies. Movements of mergers, characteristic of external growth, seem connected positively to Tobin's Q, which is against the theory (Medlen, 2003; Villieu, 2000).

The opposition between external growth and internal growth, which is the theoretical foundation of Tobin's Q, can make problem insofar as determinants which push companies to grow-up by purchasing financial assets or physical investment are the same (Bretel and alii, 1993). Finally, the relation can be reversed with concepts of widened channel and financial leverage, which are developed through a relaxation of assumptions about the distribution of information. The increase of capitalization can allow companies to obtain financial resources in two manners. One can engage a public offer of exchange by issuing shares without fear of excessive dilution insofar as the company is well evaluated by markets. More traditionally, a take over bid could be implemented by debt. A good rating allows an increase of the financial leverage effect without reaching worrying debt ratios for creditors. If it's the case, the company will be able in addition to get preferential rates (Bernanke and Gertler, 1989).

All these views lay stress on micro-foundations of macroeconomics but say few things about dynamic at the macroeconomic level. On the contrary, post-Keynesian approach is rich of explanations on the linkage between capital accumulation and income distribution. Godley's (1999), Godley and Lavoie's (2001) and Taylor's (2004) models are well fitted to study the impact of finance on accumulation and to analyse the sustainability of financial accumulation regime. Adjustments by relative assets' prices are the core of these models. Godley and Lavoie's models are studied using simulations after calibration. Those of Taylor (2004) and Dos Santos and Zezza (2004) are analyzed in a purely formal way. The point of view adopted in the present paper is different. Using the same theoretical backgrounds, we limit ourselves to preliminary econometric estimations of firms' behaviours as regard fixed capital accumulation, financial accumulation and financial liability structure in the case of the French non financial companies.

\subsection{Capital accumulation and finance: key equations}

The analysis concentrates on four main relations: fixed capital accumulation, financial accumulation and firms' demand of financial assets, credit demand and firms' indebtedness behaviour and lastly issue of equities and financial liability structure.

\section{Fixed capital accumulation}

The accumulation of capital is analyzed from a Kaleckian point of view, using as main determinants, the economic rate of profit with a positive effect (profit's accelerator), a debt ratio with the negative effect of increasing risk and a possible modulation effect at short term of the capacity utilisation rate (Kalecki, 1954). The possibility of a demand effect through a traditional demand accelerator will be examined, although this mechanism should be less important in the financial growth regime which prevails since the 1980s.

The question of the introduction of a Tobin's Q gives place to debate from a Keynesian point of view. Some Post-Keynesians authors retain such a variable (Davidson, 1972; Lavoie and Godley, 2001). Others are more divided, as various versions of the Taylor's (2004) models suggest it. Kaldor himself, however inventor before Tobin of the "valuation ratio", would have doubted of its influence on the investment decision (Lavoie and Godley, 2001). 
Lastly, instead of the Tobin Q whose role does not see clearly established, a variable of financial profitability, the rate of return on equities held, will be introduced with an effect which could be negative on the fixed capital accumulation. Booms of financial profitability would support financial accumulation at the detriment of the productive investment. The mechanism is close to the one analysed in Stockhammer (2004) but it seems preferable to use an indicator of financial profitability incorporating capital gains rather than the share of interest and dividends received in the value added.

The following specifications will be estimated

$\Delta \mathrm{K} / \mathrm{K}_{-1}=\mathrm{a}_{0}+\mathrm{a}_{1} \mathrm{R}+\mathrm{a}_{2} \mathrm{~L} /(\mathrm{L}+\mathrm{OF})+\mathrm{a}_{3} \mathrm{U}+\mathrm{a}_{4}$ ree

$\Delta \mathrm{K} / \mathrm{K}_{-1}=\mathrm{a}_{0}+\mathrm{a}_{1} \Delta \mathrm{R}+\mathrm{a}_{2} \mathrm{~L} /(\mathrm{L}+\mathrm{OF})+\mathrm{a}_{3} \mathrm{U}+\mathrm{a}_{4}$ ree (profit accelerator)

$\Delta \mathrm{K} / \mathrm{K}_{-1}=\mathrm{a}_{0}+\mathrm{a}_{1} \mathrm{R}+\mathrm{a}_{2} \mathrm{~L} /(\mathrm{L}+\mathrm{OF})+\mathrm{a}_{3} \Delta \mathrm{Y} / \mathrm{Y}_{-1}+\mathrm{a}_{4}$ ree

With $\mathrm{a}_{1}>0, \mathrm{a}_{2}<0, \mathrm{a}_{3}>0, \mathrm{a}_{4}<0$,

$\Delta \mathrm{K} / \mathrm{K}_{-1}=$ accumulation rate, $\mathrm{R}=\mathrm{P} / \mathrm{p}_{\mathrm{k}} \mathrm{K}_{-1}=$ economic rate of profit, $\mathrm{U}=$ capacity utilisation rate, $\Delta \mathrm{Y} / \mathrm{Y}_{-1}=\mathrm{GDP}$ rate of growth (accelerator effect)

$\mathrm{L} /(\mathrm{L}+\mathrm{OF})=$ share of total loans $(\mathrm{L})$ in the total liability $(\mathrm{L}+\mathrm{OF}$ with $\mathrm{OF}=$ own funds)

ree $=$ rate of return on equities held

\section{Financial accumulation}

There are few studies on the assets demand by firms whereas those of households are numerous. This can be understood because of the hybrid nature of financial assets and, particularly, of equities held by firms. However the rise of financial assets reflects new firms' behaviours since the 1980s which covers different operations: development of operations of merger-acquisition and of taking of financial stake with a perspective of domestic or foreign investment, re-purchase of shares to preserve the control or increase shares' price. The translation of these behaviours at the macroeconomic level is not straightforward.

Two directions could be explored. Firstly, the portfolio structure of firms related to their total assets could be regarded as dependant of relative rates of return of various assets, mainly the short term interest rate for monetary assets and the rate of return on equities held. An effect of financial affluence, captured through the rate of profit, could be added, this effect playing positively. Equities' demand could then be written:

$\mathrm{peEe} /\left(\mathrm{FA}+\mathrm{p}_{\mathrm{k}} \mathrm{K}\right)=\mathrm{b}_{0}+\mathrm{b}_{1} \mathrm{rm}+\mathrm{b}_{2}$ ree $+\mathrm{b}_{3} \mathrm{R}$

$b_{1}<0, b_{2}>0, b_{3}>0$

with peEe $=$ equities held by firms, $\mathrm{FA}=$ financial assets, $\mathrm{FA}+\mathrm{p}_{\mathrm{k}} \mathrm{K}=$ total assets, $\mathrm{rm}=$ short term interest rate, ree=rate of return on equities held, $\mathrm{R}=$ economic rate of profit. Another indicator of financial affluence, dividing gross profit by total assets, could be used.

Secondly, the financial rate of accumulation, measured by the ratio of new purchased equities to the previous stock, could be analysed directly with a positive influence of the rate of return of equities and an impact of the debt structure corresponding to a leverage effect. Credit cost might also play a role. In this case financial accumulation could be formalised by: 
pe $\Delta \mathrm{Ee} /(\text { peEe })_{-1}=b_{0}+b_{1}$ ree $+b_{2}\left(L / p_{k} K\right)_{-1}+b_{3} r l$

$\mathrm{b}_{1}>0, \mathrm{~b}_{2}>0, \mathrm{~b}_{3}<0$

with $\mathrm{pe} \Delta \mathrm{Ee}=$ new purchased equities, $\mathrm{rl}=$ real credit cost, $\mathrm{L} / \mathrm{p}_{\mathrm{k}} \mathrm{K}=$ debt structure with the possibility of using alternative indicators.

\section{Credit demand and indebtedness norm}

An abundant literature is devoted to this question. Three different approaches of firms' indebtedness can be distinguished. According to a first approach, a norm of indebtedness is derived both from banks' and firms' behaviour using a reduced equation. A second approach considers simultaneously two separate equations of credit demand and supply. In a last approach there is no explicit credit demand equation.

Following the first approach, firms' norm of indebtedness can be analysed through a reduced equation resulting both from banks' and firms' behaviour. Banks impose a maximum debt due to the risk of insolvency. Shareholders seek to increase financial profitability through the leverage effect, which induces a minimum debt. This analysis can be found in Breton and Aglietta (1999) and also in the macro-econometric model used at the Bank of France during the 1990s (Méfisto, 1993).

The explained variable can be defined as a capacity of long-term refunding, measured by the stock of debt divided by profit, or as a debt ratio where total loans are reported to fixed capital. Four principal explanatory variables are retained, the credit cost which plays negatively, the rate of inflation which allows a drift of the debt, the rate of accumulation which induces more debt and a ratio representing the weight of owns funds in the total liability, which also plays positively because a revalorization of owns funds authorizes a larger debt.

According to the second approach, two simultaneous equations of credit demand by firms and credit supply by banks are described, as it is developed in several models, notably in Taylor (2004). Credit demand depends negatively of credit cost and positively of the accumulation rate. Interest rate is determined by confrontation with credit supply. We are not concerned in this article by the supply side aspects but the principle of a credit demand can be retained.

In the last approach there is no credit demand as firms obtain from banks all what they need to finance their expenditures after having used the other sources (retained earnings, equities issued). There is no credit rationing from banks and money is completely endogenous, following a well established Post-Keynesian tradition (Godley, 1999; Godley and Lavoie 2001).

It is difficult to choose between these three approaches. It depends how the closure of the model is made at the macroeconomic level. In most of cases the hypothesis of endogenous money can be accepted and there is no credit supply or credit rationing. The rate of interest is controlled by the Central Bank or determined by a monetary rule. But alternatively, credit demand may be explicitly considered if, in counterpart, there is no equation describing the issue of equities or the financial liability structure, contrary to what is retained in Godley and Lavoie (2001). Lastly, credit rationing may also be analysed with a credit supply equation or, more generally, with a reduced equation resulting both from banks' and firms' behaviours. 
On the whole, these considerations plead for an examination of an equation, interpreted whether in terms of credit demand or in terms of indebtedness norm, formulated in two alternative specifications using a debt ratio $\left(\mathrm{L} / \mathrm{p}_{\mathrm{k}} \mathrm{K}\right)$ or the capacity of refunding $\left(\mathrm{L}_{-1} / \mathrm{P}\right)$ :

$\mathrm{L} / \mathrm{p}_{\mathrm{k}} \mathrm{K}=\mathrm{c}_{0}+\mathrm{c}_{1} \mathrm{rl}+\mathrm{c}_{2} \Delta \mathrm{p} / \mathrm{p}_{-1}+\mathrm{c}_{3} \mathrm{OF} /(\mathrm{L}+\mathrm{OF})+\mathrm{c}_{4} \Delta \mathrm{K} / \mathrm{K}_{-1}$

$\mathrm{L}_{-1} / \mathrm{P}=\mathrm{c}_{0}+\mathrm{c}_{1} \mathrm{rl}_{-1}+\mathrm{c}_{2} \Delta \mathrm{p} / \mathrm{p}_{-1}+\mathrm{c}_{3} \mathrm{OF} /(\mathrm{L}+\mathrm{OF})_{-1}+\mathrm{c}_{4} \Delta \mathrm{K} / \mathrm{K}_{-1}$

With $\mathrm{c}_{1}<0, \mathrm{c}_{2}>0, \mathrm{c}_{3}>0, \mathrm{c}_{4}>0$

$\mathrm{rl}=$ credit cost, $\Delta \mathrm{p} / \mathrm{p}_{-1}=$ inflation rate, $\Delta \mathrm{K} / \mathrm{K}_{-1}=$ accumulation rate, $\mathrm{OF} /(\mathrm{L}+\mathrm{OF})=$ share of own funds in total liability

At short run, a greater financial affluence, measured through the economic rate of profit $(\mathrm{R})$ or the growth rate of production $\Delta \mathrm{Y} / \mathrm{Y}_{-1}$ could reduce the recourse to debt.

\section{Issue of equities and financial liability structure}

The issue of equities and the financial liability structure is little analyzed in Post-Keynesians models. Lavoie and Godley (2001) and Taylor (2004) just postulate a simple relation of proportionality between the productive investment of the year and the flow of new issued equities, which is a highly simplified approach. Dos Santos and Zezza (2004) assume that firms keep a fixed ratio between the number of equities and the volume of fixed capital, in line with the new-Keynesian literature on equity rationing (Greenwald and Stiglitz, 1990; 1993; Hellmann and Stiglitz, 2000). Several reasons can justify this equity rationing. Issuing new equities may be considered as a negative sign by the market, being interpreted as a sign that the equity price is overvalued. More complex rules have to be followed in case of share contract than in case of a simple debt contract. Determining the amount of distributed profit is not an easy task. However equity rationing prevents firms to plainly diversify their risks, as the probability of bankruptcy is larger in case of credit financing. Assuming a fixed ratio between the number of equities and the volume of fixed capital implies a linear relation between the Tobin Q (ratio of equities on fixed capital, measured at the renewal cost), and the relative price of equities with respect to investment price.

On the other hand, in the Méfisto (1993) model of the Bank of France already mentioned, the issue of equities is determined in the long run by the rate of return on equities and comparative costs of various modes of financing. Firms operate arbitration between financing by debt and issuing equities. The structure of the financial liability (in terms of share of equities) depends thus on three series of factors. A rise in the credit cost encourages firms to more finance on own funds, whereas a rise of the rate of return on equities (re) pushes to resort to the credit. Firms are also sensible to their debt structure. A degradation of their capacity of refunding can encourage firms to finance more with issue of new equities.

Two alternative specifications can thus be proposed. The first one simply relates the share of equities in the value of productive capital, taken as a structure of balance sheet, to the relative prices of equities with respect to investment.

$\mathrm{peE} / \mathrm{p}_{\mathrm{k}} \mathrm{K}=\mathrm{d}_{0}+\mathrm{d}_{\mathrm{l}} \mathrm{pe} / \mathrm{p}_{\mathrm{k}}$

with pe $/ p_{\mathrm{k}}=$ relative price of equities with respect to investment price; $\mathrm{p}_{\mathrm{k}} \mathrm{K}=$ fixed capital measured at the renewal cost. 
The second specification focuses on the financial liability structure. Equities' share depends positively of the credit cost, negatively of the rate of return on equities and positively of the capacity of refunding.

$\mathrm{peE} /(\mathrm{L}+\mathrm{peE})=\mathrm{d}_{0}+\mathrm{d}_{1} \mathrm{rl}+\mathrm{d}_{2} \mathrm{re}+\mathrm{d}_{3} \mathrm{~L}_{-1} / \mathrm{P}+\mathrm{d}_{4} \mathrm{pe} / \mathrm{p}_{\mathrm{k}}$

$\mathrm{peE} /(\mathrm{L}+\mathrm{OF})=\mathrm{d}_{0}+\mathrm{d}_{1} \mathrm{rl}+\mathrm{d}_{2} \mathrm{re}+\mathrm{d}_{3} \mathrm{~L}_{-1} / \mathrm{P}+\mathrm{d}_{4} \mathrm{pe} / \mathrm{p}_{\mathrm{k}}$

with $\mathrm{d}_{1}>0, \mathrm{~d}_{2}<0, \mathrm{~d}_{3}>0, \mathrm{~d}_{4}>0$

$\mathrm{peE} /(\mathrm{L}+\mathrm{peE})=$ share of equities in financial liability, $\mathrm{peE} /(\mathrm{L}+\mathrm{OF})=$ share of equities in the total liability;

$\mathrm{rl}=$ credit real interest rate, $\mathrm{re}=$ rate of return on equities issued, $\mathrm{L}_{-1} / \mathrm{P}=$ capacity of refunding = total loans divided by gross profit (an increase means a deterioration of the capacity of refunding)

\section{First econometric results}

The following results only constitute a first step and would have to be prolonged by complementary estimations. They have been obtained at the level of non-financial companies for France between 1978 and 2001, with annual data to respect the coherence of flow of funds accounts established by INSEE.

The econometric relations estimated are the results of OLS or VEC estimated in one stage by the method of Engle and Granger. This method was selected for two reasons. On the one hand, some variables are non stationary variables in level, but stationary in first difference. The unit root tests are given in annex. On the other hand, in order to preserve the coherence of the flow of fund account implemented by INSEE which goes up only in 1978, we dispose only of a small degree of freedom. The small sample size and the method adopted do not make possible to directly read $t$ of Student to establish the relevance of the parameters estimated and the validity of the models selected. However the literature on the subject (Ericsson and MacKinnon (2002)) agrees to recognize the validity of a VEC estimated in one stage on small sample through a high level of T-Student. We retain a level equal to or higher to 5. Nevertheless we have conserved some equations which don't correspond to these criterions but seem interesting, even if they can be criticised from an econometric point of view. For the other variables we preserve the usual criteria (T-Student $>2$ ).

\subsection{Fixed capital accumulation}

A first equation, specified in the form of an error correction model, gives a Kaleckian relation connecting the accumulation rate and the economic rate of profit with a profit accelerator mechanism. A negative effect of the debt ratio is also significant and reflects an effect of increasing risk.

This equation can be completed in two ways. First, according to a traditional negative impact of the cost of credit on capital accumulation, the apparent real interest rate has a significant and negative effect. Secondly, at short term, a usual accelerator effect taking into account the impact of the expected variation of the demand seems significant. However it might be less important than during the demand led growth regime which prevailed during the 1960s and 1970s. 
Lastly the impact of the rate of return on equities held can be introduced. As expected, this impact is negative. The coefficient seems small but it must be recall that this indicator of financial profitability is subject to important fluctuations which can increase significantly its impact on the rate of accumulation. This result would reflect that the boom of stock exchange and the increase of financial profitability since the 1980s have contributed to slow down the accumulation of productive capital on behalf of financial accumulation. This effect remains rather robust when the traditional accelerator effect is taken into account (table 1).

On the whole, these results confirm those obtained in other investment studies in the case of France (Villeu, 2000 for a synthesis). Usual variables appear significant, although traditional problems underlined in the existing literature remain. The negative impact of financial profitability seems to confirm Stockhammer (2004) previous results. The fact that the indicator used to catch the impact of financialization is not the same, rate of return on equities held instead of the share of capital income in the value added, can be regarded as a sign of robustness.

Table 1: Fixed capital accumulation

(French non financial companies, 1980-2001)

\begin{tabular}{|c|c|c|c|c|c|c|}
\hline & $\Delta \operatorname{LogK}$ & $\Delta \mathrm{LogK}$ & $\Delta \operatorname{LogK}$ & $\Delta \log \mathrm{K}$ & $\Delta \operatorname{LogK}$ & $\Delta \log \mathrm{K}$ \\
\hline Cst & $\begin{array}{l}0.83 \\
(6.6)\end{array}$ & $\begin{array}{l}0.86 \\
(4.9)\end{array}$ & $\begin{array}{l}0.56 \\
(2.2)\end{array}$ & $\begin{array}{l}1.38 \\
(13.2)\end{array}$ & $\begin{array}{l}0.99 \\
(4.8)\end{array}$ & $\begin{array}{l}0.77 \\
(3.2)\end{array}$ \\
\hline $\operatorname{LogK}_{-1}$ & $\begin{array}{l}-0.09 \\
(-5.5)\end{array}$ & $\begin{array}{l}-0.09 \\
(-5.0)\end{array}$ & $\begin{array}{l}-0.06 \\
(-2.2)\end{array}$ & $\begin{array}{l}-0.14 \\
(-10.8)\end{array}$ & $\begin{array}{l}-0.10 \\
(-4.5)\end{array}$ & $\begin{array}{l}-0.08 \\
(-3.1)\end{array}$ \\
\hline $\mathrm{R}_{-1}$ & $\begin{array}{l}0.43 \\
(2.4)\end{array}$ & $\begin{array}{l}0.89 \\
(2.4)\end{array}$ & $\begin{array}{l}0.58 \\
(3.3)\end{array}$ & $\begin{array}{l}0.47 \\
(2.1)\end{array}$ & $\begin{array}{l}0.41 \\
(1.9)\end{array}$ & $\begin{array}{l}0.59 \\
(5.9)\end{array}$ \\
\hline $\mathrm{L} /(\mathrm{L}+\mathrm{OF})_{-1}$ & $\begin{array}{l}-1.09 \\
(-7.4)\end{array}$ & $\begin{array}{l}-1.09 \\
(-5.4)\end{array}$ & $\begin{array}{l}-0.91 \\
(-4.1)\end{array}$ & $\begin{array}{l}-1.61 \\
(-10.0)\end{array}$ & $\begin{array}{l}-1.37 \\
(-6.8)\end{array}$ & $\begin{array}{l}-1.16 \\
(-5.1)\end{array}$ \\
\hline $\mathrm{rr}_{-1}$ & & $\begin{array}{l}-0.70 \\
(-2.5)\end{array}$ & & & & \\
\hline ree $_{-1}$ & & & & $\begin{array}{l}-0.02 \\
(-2.6)\end{array}$ & $\begin{array}{l}-0.03 \\
(-2.8)\end{array}$ & $\begin{array}{l}-0.02 \\
(-2.4)\end{array}$ \\
\hline$\left(\Delta Y^{\prime} Y_{-1}\right)_{-1}$ & & & & & $\begin{array}{l}0.41 \\
(2.0)\end{array}$ & \\
\hline$\Delta_{1}^{\Delta \mathrm{L} /(\mathrm{L}+\mathrm{OF})}$ & $\begin{array}{l}-0.43 \\
(-2.1)\end{array}$ & & & & & \\
\hline$\Delta Y^{\prime} \mathrm{Y}_{-1}$ & & & $\begin{array}{l}0.70 \\
(3.1) \\
\end{array}$ & & & $\begin{array}{l}0.58 \\
(2.8) \\
\end{array}$ \\
\hline$\Delta \mathrm{R}_{-1}$ & & & & $\begin{array}{l}-0.79 \\
(-2.2)\end{array}$ & & \\
\hline $\mathrm{R}^{2}$ & 0.81 & 0.91 & 0.93 & 0.92 & 0.93 & 0.95 \\
\hline DW & 2.7 & 1.90 & 1.9 & 1.98 & 1.81 & 2.1 \\
\hline
\end{tabular}

$\mathrm{R}=$ economic rate of profit, $\mathrm{rr}=$ apparent real interest rate, ree $=$ rate of return on equities held, $\mathrm{L} /(\mathrm{L}+\mathrm{OF})=$ share of total loans in total liability, $\Delta \mathrm{Y} / \mathrm{Y}_{-1}=$ production rate of growth

\subsection{Financial accumulation}

Financial accumulation is a less explored territory from an econometric point of view. Results must be regarded as more preliminary. The demand of equities by firms can be studied through different specifications according to the ratio used to describe the asset structure. 
Equities held can be divided by total assets or only by own funds. Demand of equities would be strongly influenced by the equities rate of return. Associate to this effect, an effect of financial affluence, caught through the economic profitability, could be added. Lastly, the capacity of refunding of non financial companies could influence positively the demand of equities.

Table 2: Financial accumulation

(French non financial companies, 1980-2001)

\begin{tabular}{|l|l|l|l|}
\hline & $\Delta\left(\mathrm{peEe} / \mathrm{FA}+\mathrm{p}_{\mathrm{k}} \mathrm{K}\right)$ & $\Delta(\mathrm{peEe} / \mathrm{OF})$ & $\Delta(\mathrm{peEe} / \mathrm{OF})$ \\
\hline Cst & -0.037 & -0.04 & -0.18 \\
& $(-1.7)$ & $(-1.6)$ & $(-2.3)$ \\
\hline ree & 0.11 & 0.15 & 0.16 \\
& $(9.8)$ & $(11.9)$ & $(13.0)$ \\
\hline $\mathrm{R}$ & 0.21 & 0.22 & 0.56 \\
& $(1.4)$ & $(1.2)$ & $(1.9)$ \\
\hline $\mathrm{L}_{-1} / \mathrm{P}$ & & & 0.014 \\
& & & $(2.2)$ \\
\hline $\mathrm{R}^{2}$ & 0.86 & 0.88 & 0.89 \\
\hline $\mathrm{DW}$ & 1.3 & 1.7 & 1.86 \\
\hline
\end{tabular}

peEe=equities held, $\mathrm{FA}=$ financial assets, $\mathrm{p}_{\mathrm{k}} \mathrm{K}=$ =fixed capital, $\mathrm{OF}=\mathrm{own}$ funds, ree $=$ rate of return on equities held, $\mathrm{R}=$ economic rate of profit, $\mathrm{L}_{-1} / \mathrm{P}=$ capacity of refunding

\subsection{Indebtedness norm}

Econometric results confirm the main lines of a model interpreted in terms of indebtedness norm, resulting both from banks' and firms' behaviours. Firms' indebtedness ratio, measured by a capacity of refunding in the long run where total loans are divided by the gross profit, is related to three principal explanatory variables:

- the credit cost which plays negatively, measured with the apparent interest rate;

- the share of own funds in the total liability which plays positively, because the revalorization of own founds authorizes an increased recourse to debt, thanks to a more accommodating behaviour of banks (figure 17);

- the growth rate in volume of the production, which reflects a greater financial affluence, reduces the recourse to banks in the short run and plays negatively.

$\log \mathrm{L}_{-1} / \mathrm{P}=1.71-4.46 \mathrm{rl}+0.26 \log (\mathrm{OF} / \mathrm{L}+\mathrm{OF})-3.64 \Delta \mathrm{Y} / \mathrm{Y}_{-1} \quad \mathrm{R}^{2}=0.81 \mathrm{DW}=1.42$

$$
\text { (25.3) (-5.9) (2.9) (-7.7) }
$$

$\mathrm{L}_{-1} / \mathrm{P}=$ capacity of refunding, $\mathrm{rl}=$ credit cost, $\mathrm{OF}=$ own funds, $\mathrm{L}+\mathrm{OF}=$ total liability, $\Delta \mathrm{Y} / \mathrm{Y}_{-1}=$ rate of growth of production in volume

Figure 17 : Capacity of refunding and share of own funds 


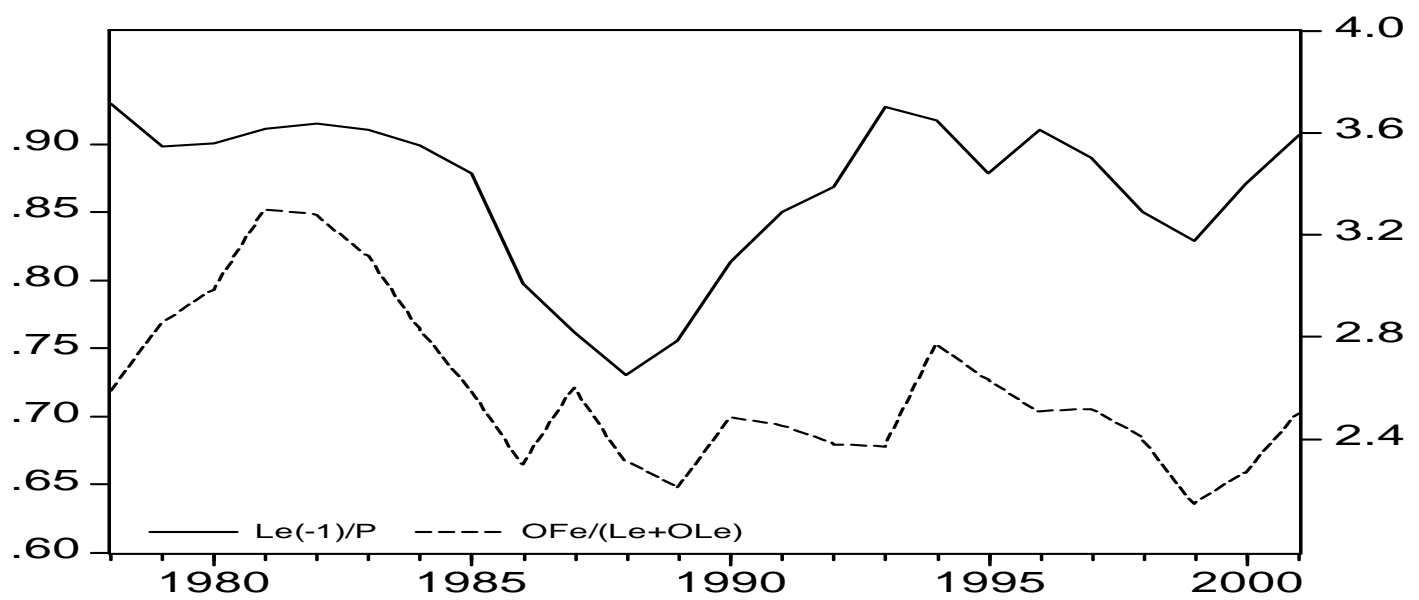

$\mathrm{L}_{-1} / \mathrm{P}=$ capacity of refunding, $\mathrm{OF} / \mathrm{L}+\mathrm{OF}=$ share of own funds in total liability

\subsection{Financial liability structure}

Some exploratory results try to check that firms operate arbitration between financing by debt and issuing shares. Two types of equations can be found in practice.

The first ones relate equities divided by non financial assets or by total assets, taken as representative of the financial liability structure, to the relative price of equities with respect to investment price. This strong relation mainly reflects that firms keep in long term a constant ratio between the number of equities issued and the stock of capital measured in real terms. It can be regarded as a first validation of the approach developed by Greenwald and Stiglitz (1990) and Dos Santos and Zezza (2004). This relation is completed by a positive influence of the economic rate of profit which reflects the economic environment.

The second equation is only related to the flows of financing. It describes explicitly how firms' arbitration between issuing new equities and financing by debt is influenced by the financial environment. The share of new issued equities divided by the total flow of financial and non financial investments is mainly determined by credit cost. An increase of real interest rate pushes firms to finance more through own funds. At short term a degradation of firms' capacity of refunding (ie, a rise of the debt-profit ratio) incites them to finance more through equities.

Table 3: Financial liability structure (French non financial companies, 1980-2001)

\begin{tabular}{|l|l|l|l|}
\hline & Log $\mathrm{peE} / \mathrm{p}_{\mathrm{k}} \mathrm{K}$ & Log $\mathrm{peE} / \mathrm{p}_{\mathrm{k}} \mathrm{K}+\mathrm{FA}$ & $\Delta\left(\mathrm{pe} \Delta \mathrm{E} /\left(\mathrm{p}_{\mathrm{k}} \mathrm{I}+\Delta \mathrm{FA}\right)\right)$ \\
\hline Cst & 3.72 & -1.77 & -0.45 \\
& $(12.5)$ & $(-8.1)$ & $(-2.3)$ \\
\hline $\mathrm{pe} / \mathrm{p}_{\mathrm{k}}$ & 0.66 & 0.40 & \\
& $(19.7)$ & $(14.5)$ & \\
\hline Log R & 0.46 & 6.45 & \\
& $(2.2)$ & $(1.6)$ & \\
\hline$\left(\mathrm{pe} \Delta \mathrm{E} /\left(\mathrm{p}_{\mathrm{k}} \mathrm{I}+\Delta \mathrm{FA}\right)\right)_{-1}$ & & & -0.63 \\
& & & $(-7.1)$ \\
\hline $\mathrm{rl}$ & & & 1.67 \\
\hline
\end{tabular}




\begin{tabular}{|l|l|l|l|}
\hline & & & $(4.1)$ \\
\hline $\mathrm{L}_{-1} / \mathrm{P}$ & & & $\begin{array}{l}0.25 \\
(2.6)\end{array}$ \\
\hline $\mathrm{R}^{2}$ & & & 0.40 \\
\hline $\mathrm{DW}$ & 0.99 & 0.97 & 2.2 \\
\hline
\end{tabular}

$\mathrm{peE}=$ issued equities, $\mathrm{p}_{\mathrm{k}} \mathrm{K}=$ fixed capital stock, $\mathrm{FA}=$ total financial assets, $\mathrm{p}_{\mathrm{k}} \mathrm{K}+\mathrm{FA}=$ total assets, $\mathrm{pe} \Delta \mathrm{E}=$ new issued equities, $\left(\mathrm{p}_{\mathrm{k}} \mathrm{I}+\Delta \mathrm{FA}\right)=$ increase of financial and non financial investments, $\mathrm{pe} / \mathrm{p}_{\mathrm{k}}=$ equities price relative to investment price, $\mathrm{R}=$ economic rate of profit, $\mathrm{rl}=$ credit cost measured with apparent real interest rate, $\mathrm{L}_{-1} / \mathrm{P}=$ capacity of refunding

\section{Conclusion}

The paper is focused on the nature of the growth regime which prevailed in France since the middle of the 1980s and on the role plaid by finance. The analysis has been made at the level of non financial companies with annual data from flow of funds accounts of INSEE. The main features of this growth regime have been a recovery of profitability with a persistent mass unemployment and without durable resumption of growth or accumulation of productive capital. The financialization can be read in the balance sheet structure of firms with rising shares of equities, both at the asset and liability sides. In a context of declining interest rates since the middle of the 1980s, the boom of equities prices, stopped by two crises in 1987 and 2001, contributed to own funds' and financial assets' revalorisation, while financial profitability knew cyclical and large amplitude evolutions.

Financial profitability is mainly determined by capital gains, i.e. fluctuations of equities prices. In that respect, a high and sustainable norm of financial rate of profit seems difficult to satisfy. Furthermore, it can hardly be argued that net financial burden has increased. After an increase at the beginning of the 1980s due to the rise of interest rates, the net financial burden in percentage of gross profit has declined and remained stable during the 1990s, thanks to the rise of financial assets and the sustained growth of financial income.

Following a Post-Keynesian framework, the main determinants of capital accumulation and finance have been analysed and tested. According to Kaleckian principles, the accumulation of productive capital appeared largely driven by the economic rate of profit and available finance. But the financial rate of profit, i.e. the rate of return on equities held, seems to exercise a negative effect. In that respect the boom of stock exchange and the increase of financial profitability could have contributed to slow down the accumulation of productive capital on behalf of financial accumulation. Indeed, the demand of equities by firms is rather strongly influenced by the rate of return on equities. This arbitration, which seems to prevail between real and financial accumulation, could contribute to explain the insufficient recovery of investment which is one of the determining factors of the weakness of growth and employment in France, as in many other European countries.

Regarding liability structure, two alternative approaches have been considered, one in terms of indebtedness norm, the other in terms of arbitration between financing by debt and issuing shares. A model in terms of indebtedness norm can be interpreted as a reduced form resulting both from banks' and firms' behaviours. Two determinants have been drawn out. As usual the debt ratio would depend negatively from credit cost. But a revalorization of own funds or an improvement of economic environment would also facilitate the recourse to credit.

The way firms operate arbitration between financing by debt and issuing shares is an alternative approach of the liability structure. In terms of stocks, it appeared that in long term firms would keep a constant ratio between the number of equities issued and the stock of 
capital measured in real terms. In terms of flows, issuing new equities would be encouraged by an increase of credit cost, but also at short term by a worsening of the debt ratio.

These first results would have to be checked by more elaborate analysis. Comparisons with other countries would be instructive. Lastly, the building of a macroeconomic model in lines of Godley and Lavoie (2001) would help to evaluate more precisely the nature of a finance growth led regime by opposition to demand led or profit led growth regime which are more usually analysed. 


\section{Bibliography}

Aglietta, M., 2000 "Shareholder value and corporate governance: some tricky questions". Economy and Society Volume 29 Number 1 February 2000: 146-159

Aglietta M and Breton R., 2001 «Financial systems, corporate control and capital accumulation », Economic and Society, November

Aglietta M. and Reberioux A., 2004 "Corporate governance adrift: a critique of shareholder value", Edward Elgar.

Arestis P., 2004 "Washington consensus and financial liberalization" p.251-271, Journal of Post Keynesian Economics, winter 2004-5, Vol.27 No.2

Ashworth P. and Davis E. P., 2001 "Some evidence on financial factors in the determination of aggregate business investment for the G7 economies", NIESR Discussion paper, $\mathrm{n}^{\circ} 187$

Banque de France, 1993, "Mefisto : la maquette du système financier français de la Banque de France », Cahiers Economiques et Monétaires $n^{\circ}$ 42, p 41-95.

Bataille E and Durant D., 2005 « Mesures de la rentabilité des entreprises », Bulletin de la Banque de France, $n^{\circ} 134$, février

Bernanke B.S and Gertler M., 1989 "Agency Cost, Collateral, and Business Fluctuations" AER, 79(1) 14-31

Billaudot B., 2001 Régulation et croissance. Une macroéconomie historique et institutionnelle. L'Harmattan. Collection Théorie sociale contemporaine.

Boyer R., 2000 "Is a finance-led growth regime a viable alternative to Fordism? A preliminary analyse". Economy and Society Volume 29 Number 1 February 2000: 111-145

Bretel B., Caubet-Hilloutou J. N., Di Carlo L., Epaulard A., 1993 «Quels sont les déterminants de la croissance externe des entreprises française?», Economie \& Prévision $\mathrm{n}^{\circ} 109$ 1993-3

Chesnais F., coord., 1996, La mondialisation financière: Genèse, coût et enjeux. Editions La Découverte et Syros

Clévenot, M. 2003 «Les méthodes développées par la Stock Flow Consistent Approach à la lumière de la Théorie de la Régulation ». Actes du Forum de la régulation, 9-10 octobre

Davidson P. 1972 « Money in the real world», New York, John Wiley

Dos Santos C. 2004 "Keynesian Theorizing During Hard Times: Stock-Flow Consistent Models as an Unexplored "Frontier" of Keynesian Macroeconomics", May, Levy Institute WP 408

Dos Santos C. and Zezza G., 2005 "A simplified Stock Flow Consistent Post-Keynesian growth model", Levy Institute WP

Duménil G. and Levy D., 2004, Capital resurgent, Roots of the neo-liberal revolution, Harvard University Press.

Epaulard A. 1993 «L'apport du Q de Tobin à la modélisation de l'investissement en France », Economie \& Prévision nº109 1993-3

Ericsson N. and MacKinnon J. 2002 "Distributions of error correction tests for cointegration", Econometrics Journal, volume 5, pp. 285-318.

Godley,W. 1999 "Money, and Credit in a Keynesian Model of Income Determination" Cambridge journal of Economics 23 (4): July.

Godley,W and Cripps, F. 1983 Macroeconomics. Oxford University Press

Greenwald, B. and Stiglitz, J. E., 1990 "Macroeconomic models with equity and credit rationing" in Hubbard R. B., ed. Asymmetric information, corporate finance and investment, Chicago University Press, pp 15-42.

Greenwald, B. and Stiglitz, J. E., 1993 "Financial market imperfections and business cycles", Quaterly Journal of Economics, 108, 1, pp 77- 114

Hellmann, T. and Stiglitz J. E., 2000 "Credit and equity rationing in markets with adverse selection”, European Economic Review, 44, 2, pp 281-304 
Kalecki M., 1937, "A theory of business cycle”, The Review of Economic Studies, vol 4, n², February, pp 77-97.

Kalecki M., 1954, Theory of economic dynamics, an essay on cyclical and long run changes in capitalist economy, Ed Georges Allen \& Unwin.

Lavoie, M and Godley, W. 2001 "Kaleckian models of growth in a coherent stock-flow monetary framework: a Kaldorian view." Journal of Post Keynesian Economics, 24(2): 277312

Medlen C. 2003 "The trouble with Q" Journal of Post Keynesian Economics Summer 2003, Vol. 25, $\mathrm{n}^{\circ} 4$

Minsky H., 1986 “Stabilizing an unstable economy”, Yale University Press.

Modigliani and Miller (1958) « The cost of capital, Corporation Finance, and the Theory of Investment" American Economic Review, vol 48, June, pp 261-297

Plihon, D 2002 (Sous la direction de) «Rentabilité et risque dans le nouveau régime de croissance ». Rapport du Plan. La documentation française.

Stochmammer, E. 2004 "Financialization and the slowdown of accumulation", Cambridge Journal of Economics, vol 28, $\mathrm{n}^{\circ}$ 5, September, pp 719-742

Stochmammer, E. 2004 "The Rise of European unemployment: A Synopsis" Working paper n76 Political Economy Research Institute http://www.umass.edu/peri/pdfs/WP76.pdf

Taylor, L. 2004 Reconstrucing macroeconomics : structuralist proposals and critiques on the mainstream. Harvard University Press

Vidal. J. F 2002. «Les bouleversements du régime d'accumulation et les ajustements de la régulation : la croissance française sans mythes ». L'année de la régulation $\mathrm{n}^{\circ} 6,2002-2003$. Presses de Science Po.

Vidal. J. F 2003. «Régime de croissance post-fordistes : comparaison des Etats-Unis, du Japon et de la France ». Actes du Forum de la régulation, 9-10 octobre

Villeu P. 2000, Macroéconomie. L'investissement Editions La Découverte, Collection Repères $n^{\circ} 276$. 
Annex: Augmented Dickey-Fuller Test :

\begin{tabular}{|c|c|c|}
\hline Variable & ADF t-statistic & ADF probability \\
\hline Log K with constant and trend & -3.08 & $13 \%$ \\
\hline $\mathrm{D}(\log (\mathrm{K}))$ & -2.68 & $9 \%$ \\
\hline $\mathrm{R}$ with intercept and trend & -3.60 & $6 \%$ \\
\hline $\mathrm{D}(\mathrm{R})$ with intercept and trend & -5.34 & $0 \%$ \\
\hline $\mathrm{L} /(\mathrm{L}+\mathrm{OF})$ & -3.74 & $5 \%$ \\
\hline $\mathrm{D}(\mathrm{L} /(\mathrm{L}+\mathrm{OF}))$ & -3.39 & $0 \%$ \\
\hline mree with intercept & -4.56 & $0 \%$ \\
\hline $\mathrm{D}$ (mree) & -3.27 & $0 \%$ \\
\hline Ree & -4.08 & $0 \%$ \\
\hline $\mathrm{D}$ (ree) & -5.98 & $0 \%$ \\
\hline $\mathrm{peE} /(\mathrm{L}+\mathrm{peE})$ with intercept & -2.30 & $18 \%$ \\
\hline $\mathrm{D}(\mathrm{peE} /(\mathrm{L}+\mathrm{peE}))$ & -3.47 & $0 \%$ \\
\hline $\mathrm{Rn}$ & -2.79 & $0 \%$ \\
\hline $\mathrm{D}(\mathrm{rn})$ with intercept & -5.57 & $0 \%$ \\
\hline $\mathrm{Pe}$ & 1.10 & $92 \%$ \\
\hline $\mathrm{D}(\mathrm{pe})$ & -2.62 & $1 \%$ \\
\hline $\mathrm{peE} / \mathrm{FL}$ & 1.03 & $91 \%$ \\
\hline $\mathrm{D}(\mathrm{peE} / \mathrm{FL})$ & -3.61 & $0 \%$ \\
\hline $\log (\mathrm{L}(-1) / \mathrm{P})$ & -2.75 & $8 \%$ \\
\hline $\mathrm{D}(\log (\mathrm{L}(-1) / \mathrm{P}))$ & -2.95 & $0 \%$ \\
\hline $\log (\mathrm{OF} /(\mathrm{L}+\mathrm{peE}))$ with intercept & -2.73 & $8 \%$ \\
\hline $\mathrm{D}(\log (\mathrm{OF} /(\mathrm{L}+\mathrm{peE})))$ & -4.03 & $0 \%$ \\
\hline D(GDP)/GDP(-1) with intercept & -2.65 & $9 \%$ \\
\hline $\mathrm{D}(\mathrm{D}(\mathrm{GDP}) / \mathrm{GDP}(-1))$ with intercept & -5.55 & $0 \%$ \\
\hline peEe/FA with intercept and trend & -3.43 & $8 \%$ \\
\hline $\mathrm{D}(\mathrm{peEe} / \mathrm{FA})$ & -2.92 & $0 \%$ \\
\hline peEe/(Me+peEe) with intercept & -2.57 & $12 \%$ \\
\hline $\mathrm{D}(\mathrm{peEe} /(\mathrm{peEe}+\mathrm{Me}))$ & -2.91 & $0 \%$ \\
\hline $\log ($ IPA/KP95) & -1.67 & $8 \%$ \\
\hline $\mathrm{D}(\log (\mathrm{IPA} / \mathrm{KP} 95)$ & -3.61 & $0 \%$ \\
\hline peE/OF with trend and intercept & -2.32 & $40 \%$ \\
\hline $\mathrm{D}(\mathrm{peE} / \mathrm{OF})$ & -4.33 & $0 \%$ \\
\hline $\mathrm{peE} / \mathrm{KP}$ & -3.16 & $12 \%$ \\
\hline $\mathrm{D}(\mathrm{peE} / \mathrm{KP})$ & -3.58 & $0 \%$ \\
\hline $\mathrm{peE} / \mathrm{K}$ & 0.49 & $81 \%$ \\
\hline $\mathrm{D}(\mathrm{peE} / \mathrm{K})$ & -3.57 & $0 \%$ \\
\hline
\end{tabular}

